\title{
Diversity of the diatom genus Fragilariopsis in the Argentine Sea and Antarctic waters: morphology, distribution and abundance
}

\author{
Adrián O. Cefarelli • Martha E. Ferrario • \\ Gastón O. Almandoz • Adrián G. Atencio • \\ Rut Akselman • María Vernet
}

Received: 9 October 2009/Revised: 2 March 2010/Accepted: 12 March 2010/Published online: 16 October 2010

(C) The Author(s) 2010. This article is published with open access at Springerlink.com

\begin{abstract}
Fragilariopsis species composition and abundance from the Argentine Sea and Antarctic waters were analyzed using light and electron microscopy. Twelve species $(F$. curta, $F$. cylindrus, $F$. kerguelensis, $F$. nana, $F$. obliquecostata, F. peragallii, $F$. pseudonana, F. rhombica, $F$. ritscheri, $F$. separanda, $F$. sublinearis and $F$. vanheurckii) are described and compared with samples from the Frenguelli Collection, Museo de La Plata, Argentina. F. peragallii was examined for the first time using electron microscopy, and $F$. pseudonana was recorded for the first time in Argentinean shelf waters. New information on the girdle view is included, except for the species $F$. curta, F. cylindrus and $F$. nana, for which information already existed. In the Argentine Sea, F. pseudonana was the most abundant Fragilariopsis species, and in Antarctic waters, F. curta was most abundant. Of the twelve species of Fragilariopsis documented, four occurred in the Argentine Sea, nine in the
\end{abstract}

\footnotetext{
A. O. Cefarelli $(\bowtie) \cdot$ M. E. Ferrario · G. O. Almandoz .

A. G. Atencio

Departamento Científico Ficología, Facultad de Ciencias Naturales y Museo, Universidad Nacional de La Plata, Paseo del Bosque s/n, 1900 La Plata, Argentina

e-mail: acefarelli@fcnym.unlp.edu.ar
}

M. E. Ferrario - G. O. Almandoz · A. G. Atencio CONICET, Consejo Nacional de Investigaciones Científicas y Técnicas, Av. Rivadavia 1917 (1033), Buenos Aires, Argentina

\section{R. Akselman}

Instituto Nacional de Investigación y Desarrollo Pesquero, V. Ocampo 1, Escollera Norte, B7602HSA Mar del Plata, Argentina

\section{Vernet}

Integrative Oceanography Division, Scripps Institution of Oceanography, University of California San Diego, La Jolla, CA 92093-0218, USA
Drake Passage and twelve in the Weddell Sea. F. curta, $F$. kerguelensis, F. pseudonana and F. rhombica were present everywhere.

Keywords Phytoplankton · Diatom - Fragilariopsis . Antarctica $\cdot$ Argentine Sea

\section{Introduction}

The Argentine Sea, the Polar Front and the Weddell Sea are characterized by high primary productivity and rich phytoplankton communities (Longhurst 1998; Romero et al. 2006; Schloss et al. 2007). Phytoplankton are the main source of organic carbon in the ocean and are subject to high spatial variability and strong seasonality (Fischer et al. 2002). The abundance, composition and cell size distribution of phytoplankton communities influence the flow of organic carbon in pelagic waters (Schloss and Estrada 1994). Large phytoplankton organisms (microplankton, $>20 \mu \mathrm{m}$ ) are commonly associated with productive areas in the Southern Ocean, while smaller flagellates (nanoplankton, 2-20 $\mu \mathrm{m}$ ) dominate areas of lower productivity (Fryxell 1989; Kang and Fryxell 1993). Diatoms in chains and Phaeocystis antarctica Karsten are found at the ice edge in the spring as well as at oceanic fronts (Kang et al. 2001; Krell et al. 2005). Diatoms such as Fragilariopsis curta (van Heurck) Hustedt and F. cylindrus (Grunow ex Cleve) Frenguelli can dominate the water column, sea ice and iceedge communities (Garrison et al. 1987; Garrison and Buck 1989; Kang and Fryxell 1993; Socal et al. 1997; Hegseth and von Quillfeldt 2002). Nanoplankton is usually characterized by cryptomonads, single cell Phaeocystis antarctica, Pyramimonas spp. and small diatom species (Garibotti et al. 2003). 
The predominance of diatoms in the Southern Ocean has been well documented and was first described in early research expeditions (Hooker 1844). Productive areas, such as the Western Antarctic Peninsula (Walsh et al. 2001; Garibotti et al. 2003; Prézelin et al. 2004), the Weddell Sea (Fryxell and Kendrick 1988), Prydz Bay (Kopczyńska et al. 1995), the Bellingshausen Sea (Barlow et al. 1998; van Leeuwe et al. 1998) and the Ross Sea (Arrigo et al. 1999), tend to be rich in diatoms (Kopczyńska et al. 2007; Kozlowski 2008). Productive waters of the Argentine Sea (Southwestern South Atlantic) are also rich in diatoms (e.g., Carreto et al. 1981; Akselman 1996; Almandoz et al. 2007). Diatoms can be identified by microscopy, pigment content or genetic analyses. The need for improved methods to identify diatoms as well as additional information to improve the use of existing techniques is an ongoing research effort.

Fragilariopsis Hustedt is a marine diatom genus that includes planktonic, a few benthic and some ice-associated species (Hasle and Medlin 1990; Round et al. 1990). Many of them are well preserved in marine sediments and are used in paleoceanography for past productivity estimates (e.g., Zielinski and Gersonde 1997; Abelmann et al. 2006). Fragilariopsis has a wide geographical distribution but is mainly found in polar waters, especially Antarctica, where many species can be found, usually in great abundance (Frenguelli 1943; Frenguelli and Orlando 1958, 1959; Hasle and Medlin 1990; Round et al. 1990). However, $F$. pseudonana (Hasle) Hasle is a cosmopolitan species, and F. doliolus (Wallich) Medlin and Sims is restricted to warm waters (Hasle 1976; Medlin and Sims 1993; Hasle and Syvertsen 1997). Some Fragilariopsis species are found in the Southwestern Atlantic Ocean (Brandini et al. 2000; Romero and Hensen 2002; Olguín et. al 2006), but their occurrence in Argentine shelf waters is poorly documented (Ferrario and Galván 1989; Vouilloud 2003).

The genus Fragilariopsis was established by Hustedt in 1913 by separating Fragilariopsis from the genus Fragilaria Lyngbye. In 1972, Hasle reduced Fragilariopsis to a section of the genus Nitzschia Hassall, arguing that a real difference between these genera did not exist. In 1990, Round et al. preferred to give Fragilariopsis generic status in view of the enormous diversity already present in Nitzschia and considering that Fragilariopsis appeared to be a natural group. Later, in 1993, Hasle recognized Fragilariopsis to generic status, emending its diagnosis and making new combinations. However, the molecular analyses indicated that Fragilariopsis and Pseudo-nitzschia are very closely related genera and they might be congeneric (Lundholm et al. 2002). The cells in Fragilariopsis are usually united by the whole or the majority of the valve face into flat, ribbon-like colonies; single cells appear only occasionally. The frustules are rectangular in girdle view, elliptical-linear-lanceolate, and isopolar or heteropolar in valve view. The canal raphe is markedly eccentric, not raised above the level of the valve and without poroids in the outer wall (Hasle 1965, 1993; Round et al. 1990). The valve striae are separated by robust interstriae and generally have two rows of poroids (rarely more than two and sometimes only one). In general, the striae are parallel, except near the poles (Round et al. 1990; Hasle and Syvertsen 1997). The valve mantle can be unperforated or can have striae with one or more rows of poroids. Girdle bands are unperforated or show one or more rows of poroids (Hasle 1965; Medlin and Sims 1993). In general, there is little information on the girdle view of the different Fragilariopsis species. The cells have two chloroplasts, one at each side of the median transapical plain (Hasle and Syvertsen 1997).

Diatom samples from Antarctica and Argentina, collected by Dr. Joaquín Frenguelli (1883-1958) and others, are catalogued and compiled as the "Colección de Diatomeas Argentinas Dr. J. Frenguelli". The collection is located at the Museo de La Plata, La Plata, Argentina. Permanent slides $(2,435)$ are catalogued and organized by sample (Ferrario et al. 1995). With 459 new taxa (genera, species, varieties and forms) and 38 type materials from Antarctica, Frenguelli's collection is frequently consulted for taxonomic studies (e.g., Hasle 1964, 1965; Simonsen 1974; Ferrario et al. 2008; Fernandes and Sar 2009). As the collection includes multiple Fragilariopsis species, we consulted it for this study (Frenguelli 1943, 1960; Frenguelli and Orlando 1958, 1959).

The objective of this study was to identify and describe the Fragilariopsis diatom species found in neritic and oceanic surface waters of the Argentine Sea, Drake Passage and Weddell Sea by light and electron microscopy. Twelve species were documented. Previous descriptions on Fragilariopsis species were expanded, and important details on girdle view were provided for the first time. $F$. peragallii (Hasle) Cremer was examined for the first time using electron microscopy. Species relative abundance and concentration were given and compared with abundance of other diatom species and total phytoplankton.

\section{Materials and methods}

The present work is based on the analysis of phytoplankton samples collected in the South Atlantic and Antarctic waters. During the expedition ARGAU I Project "Cooperation Program between France and ARGentina for the study of the AUstral Atlantic Ocean" (19-26 February 2001), 36 quantitative and qualitative samples were collected onboard the icebreaker ARA Almirante Irizar along three north-south transects: (1) continental shelf of the 
Argentine Sea (AS), (2) Drake Passage (DP) and (3) Weddell Sea (WS) (Fig. 1; Table 1). Water temperature and salinity were measured with Sea-Bird SB 38 and 37 sensors, respectively.

During the expedition GEF I Project "GEF-Patagonia" (8-28 October 2005), qualitative samples were collected onboard the ARA Puerto Deseado along the continental shelf of the Argentine Sea (Fig. 1).

During the expeditions Iceberg I and Iceberg II Project "Free-drifting Icebergs as Proliferating Dispersion Sites of Iron Enrichment, Organic Carbon Production and Export in the Southern Ocean" (3-28 December 2005 and 31 May to 30 June 2008, respectively), qualitative samples were collected onboard the ARSV Laurence M. Gould and ARIB Nathaniel B. Palmer, respectively, at the Scotia Sea and Weddell Sea (Fig. 1).
Quantitative samples from ARGAU I were collected from the seawater intake at $9 \mathrm{~m}$ depth through a pumping system that did not break delicate planktonic organisms (Balestrini et al. 2000); qualitative samples from ARGAU I, GEF I and Iceberg II were collected by net with a mesh size of $20 \mu \mathrm{m}$, and the samples from Iceberg I were collected from a Phantom DS-2 remote operating vehicle (ROV) (Smith et al. 2007). Both types of samples were preserved with Lugol's iodine solution.

The morphological analyses were based on the qualitative samples. Whole cells as well as diatom frustules cleaned of organic matter (Hasle and Fryxell 1970) were mounted on permanent microscope slides using Naphrax medium (Ferrario et al. 1995). Whole cells were mounted in Naphrax in order to prevent specimens from being lost and so that certain characteristics could be observed

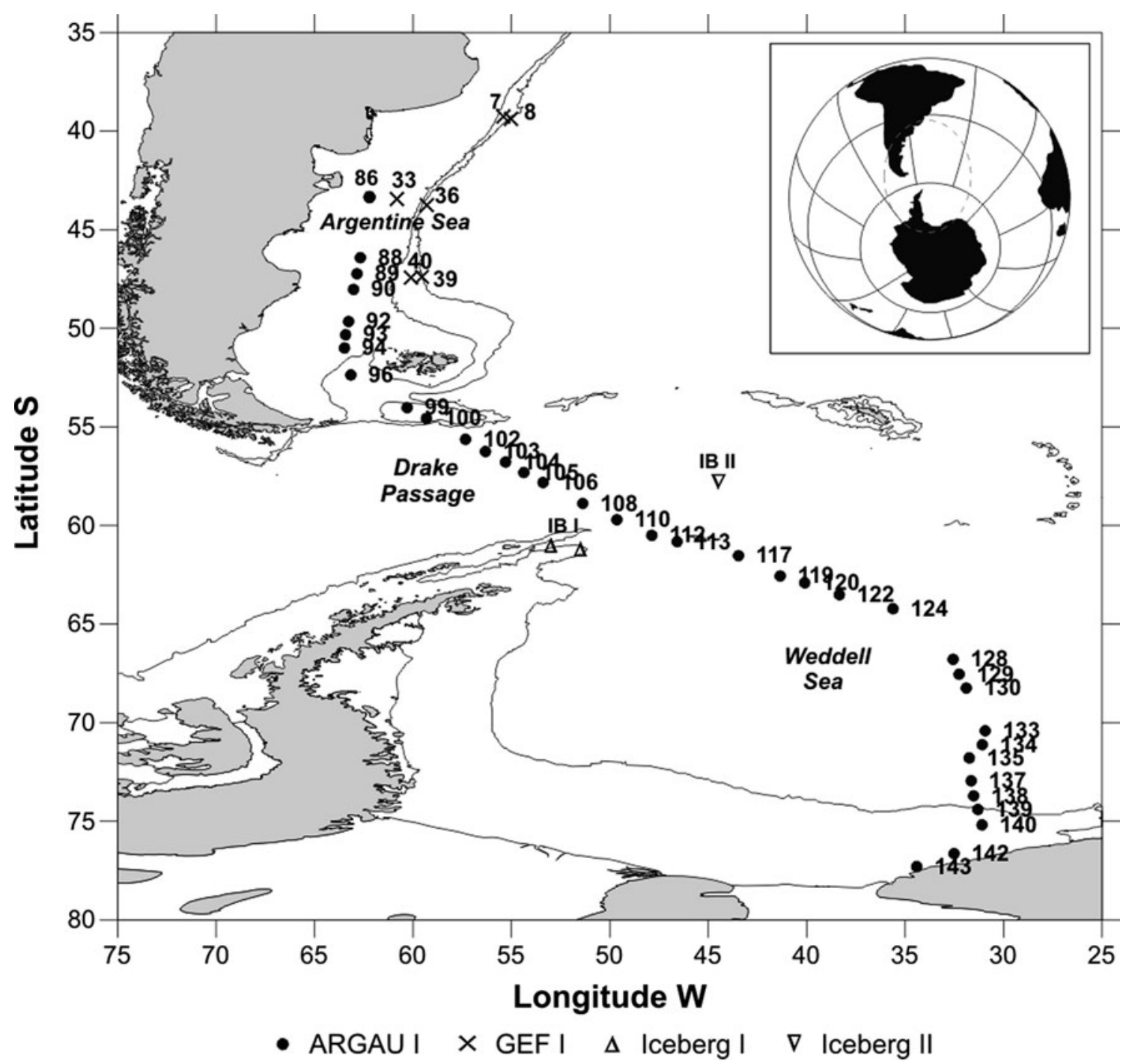

Fig. 1 Map showing the sampling locations in the Argentine Sea, Drake Passage and Weddell Sea 
Table 1 Environmental information on the transect sampled during ARGAU I, 19-26 February 2001

\begin{tabular}{|c|c|c|c|c|c|}
\hline Area & Station & $\begin{array}{l}\text { Latitude } \\
\text { S }\end{array}$ & $\begin{array}{l}\text { Longitude } \\
\text { W }\end{array}$ & $\begin{array}{l}\text { Temperature } \\
\left({ }^{\circ} \mathrm{C}\right)\end{array}$ & $\begin{array}{l}\text { Salinity } \\
\text { (PSU) }\end{array}$ \\
\hline \multirow[t]{10}{*}{ AS } & 86 & $43^{\circ} 21^{\prime}$ & $62^{\circ} 12^{\prime}$ & 17.00 & 33.46 \\
\hline & 88 & $46^{\circ} 25^{\prime}$ & $62^{\circ} 40^{\prime}$ & 14.06 & 33.60 \\
\hline & 89 & $47^{\circ} 14^{\prime}$ & $62^{\circ} 50^{\prime}$ & 13.35 & 33.57 \\
\hline & 90 & $48^{\circ} 02^{\prime}$ & $63^{\circ} 01^{\prime}$ & 12.88 & 33.56 \\
\hline & 92 & $49^{\circ} 39^{\prime}$ & $63^{\circ} 16^{\prime}$ & 10.66 & 33.63 \\
\hline & 93 & $50^{\circ} 20^{\prime}$ & $63^{\circ} 25^{\prime}$ & 9.72 & 33.62 \\
\hline & 94 & $51^{\circ} 00^{\prime}$ & $63^{\circ} 29^{\prime}$ & 9.38 & 33.71 \\
\hline & 96 & $52^{\circ} 22^{\prime}$ & $63^{\circ} 09^{\prime}$ & 8.02 & 33.85 \\
\hline & 99 & $54^{\circ} 02^{\prime}$ & $60^{\circ} 18^{\prime}$ & 7.36 & 34.08 \\
\hline & 100 & $54^{\circ} 35^{\prime}$ & $59^{\circ} 19^{\prime}$ & 7.22 & 34.06 \\
\hline \multirow[t]{7}{*}{ DP } & 102 & $55^{\circ} 38^{\prime}$ & $57^{\circ} 20^{\prime}$ & 6.15 & 34.09 \\
\hline & 103 & $56^{\circ} 15^{\prime}$ & $56^{\circ} 19^{\prime}$ & 6.22 & 34.11 \\
\hline & 104 & $56^{\circ} 47^{\prime}$ & $55^{\circ} 18^{\prime}$ & 6.22 & 34.10 \\
\hline & 105 & $57^{\circ} 19^{\prime}$ & $54^{\circ} 22^{\prime}$ & 3.41 & 33.72 \\
\hline & 106 & $57^{\circ} 49^{\prime}$ & $53^{\circ} 23^{\prime}$ & 4.33 & 33.89 \\
\hline & 108 & $58^{\circ} 53^{\prime}$ & $51^{\circ} 23^{\prime}$ & 2.70 & 33.83 \\
\hline & 110 & $59^{\circ} 43^{\prime}$ & $49^{\circ} 38^{\prime}$ & 1.97 & 34.15 \\
\hline \multirow[t]{19}{*}{ WS } & 112 & $60^{\circ} 30^{\prime}$ & $47^{\circ} 52^{\prime}$ & 0.72 & 33.98 \\
\hline & 113 & $60^{\circ} 49^{\prime}$ & $46^{\circ} 35^{\prime}$ & -0.09 & 33.90 \\
\hline & 117 & $61^{\circ} 32^{\prime}$ & $43^{\circ} 28^{\prime}$ & -0.17 & 33.65 \\
\hline & 119 & $62^{\circ} 34^{\prime}$ & $41^{\circ} 21^{\prime}$ & -1.15 & 33.17 \\
\hline & 120 & $62^{\circ} 54^{\prime}$ & $40^{\circ} 06^{\prime}$ & -0.81 & 33.29 \\
\hline & 122 & $63^{\circ} 31^{\prime}$ & $38^{\circ} 21^{\prime}$ & -1.20 & 33.10 \\
\hline & 124 & $64^{\circ} 13^{\prime}$ & $35^{\circ} 37^{\prime}$ & -0.47 & 33.56 \\
\hline & 128 & $66^{\circ} 48^{\prime}$ & $32^{\circ} 34^{\prime}$ & -0.12 & 33.74 \\
\hline & 129 & $67^{\circ} 33^{\prime}$ & $32^{\circ} 16^{\prime}$ & -0.37 & 33.72 \\
\hline & 130 & $68^{\circ} 15^{\prime}$ & $31^{\circ} 54^{\prime}$ & -0.52 & 33.74 \\
\hline & 133 & $70^{\circ} 25^{\prime}$ & $30^{\circ} 56^{\prime}$ & -0.21 & 33.50 \\
\hline & 134 & $71^{\circ} 07^{\prime}$ & $31^{\circ} 05^{\prime}$ & -0.57 & 33.61 \\
\hline & 135 & $71^{\circ} 47^{\prime}$ & $31^{\circ} 45^{\prime}$ & -1.33 & 33.33 \\
\hline & 137 & $72^{\circ} 57^{\prime}$ & $31^{\circ} 39^{\prime}$ & -1.60 & 33.39 \\
\hline & 138 & $73^{\circ} 43^{\prime}$ & $31^{\circ} 31^{\prime}$ & -1.33 & 33.52 \\
\hline & 139 & $74^{\circ} 24^{\prime}$ & $31^{\circ} 19^{\prime}$ & -0.74 & 33.90 \\
\hline & 140 & $75^{\circ} 11^{\prime}$ & $31^{\circ} 06^{\prime}$ & -0.67 & 33.92 \\
\hline & 142 & $76^{\circ} 38^{\prime}$ & $32^{\circ} 31^{\prime}$ & -0.97 & 34.24 \\
\hline & 143 & $77^{\circ} 18^{\prime}$ & $34^{\circ} 25^{\prime}$ & -0.97 & 34.21 \\
\hline
\end{tabular}

The polar front was encountered at 56 $54^{\prime}$ S, between stations 104 and 105. AS Argentine Sea, DP Drake Passage, WS Weddell Sea

without deterioration (Ferrario et al., op. cit.). The material was examined with a phase contrast Leica DM 2500 light microscope (LM) equipped with a Leica DFC420 digital camera. Furthermore, this material was mounted on stubs and coated with gold-palladium (Ferrario et al. 1995) and examined with a Jeol JSM-6360 LV scanning electron microscope (SEM, Museo de La Plata, Argentina). Complementary examinations were carried out by using a JEOL
$1200 \mathrm{EX}$ transmission electron microscope (TEM) at the Universidad Nacional Autónoma de México (UNAM). Permanent glass slides have been stored at the Herbarium of the Departamento Científico Ficología, Facultad de Ciencias Naturales y Museo, Universidad Nacional de La Plata, La Plata, Argentina. When appropriate, our material was compared with the Colección de Diatomeas Argentinas Dr. J. Frenguelli to confirm species identification, synonyms and transfers (Frenguelli 1943, 1960; Frenguelli and Orlando 1958, 1959). Terminology follows Round et al. (1990) and Hasle and Syvertsen (1997).

To obtain the Fragilariopsis species morphometric data, the valve width as well as that of the mantle and the girdle bands were measured at the middle part of non-tilted frustules.

To estimate the relative abundance of the Fragilariopsis species within the genus, all specimens (from $\sim 100$ to $1,000)$ present in the permanent glass slides prepared from the net samples collected during ARGAU I were counted at 1000X magnification using LM and oil immersion, and the results are expressed as percentages.

The quantitative samples from ARGAU I were used for calculating cell density by counting at $400 \mathrm{X}$ magnification with an Iroscope SI-PH inverted microscope (Utermöhl 1958). Previously, $100 \mathrm{ml}$ of each sample was settled for $48 \mathrm{~h}$ in sedimentation chambers. At least 300 individuals were counted in random fields of view, and the results were converted to number of cells per liter of water. Identification of individual cells was performed to the lowest possible taxonomical level, i.e. most diatoms were identified to genus or species level. However, small flagellates $(\leq 5 \mu \mathrm{m})$ were lumped into the category "unidentified phytoflagellates".

\section{Results and discussion}

Description of Fragilariopsis species

Fragilariopsis curta (van Heurck) Hustedt

(Figs. 2a-d, 7a, b)

Hustedt (1958): 160, pl. 11, figs 140-144; pl. 12, fig. 159. Frenguelli and Orlando (1958): 107, pl. 4, figs 29-31. Frenguelli (1960): 21. Hasle (1965): 32, 33, pl. 6 , fig. 6 ; pl. 12 , figs $2-5$; pl. 13 , figs $1-6$; pl. 16 , fig. 6 ; pl. 17, fig. 5

Basionym: Fragilaria curta van Heurck

Synonyms: Fragilariopsis linearis var. curta (van Heurck) Frenguelli in Frenguelli and Orlando. Nitzschia curta (Van Heurck) Hasle

The valve shape is linear and heteropolar, with one end wider than the other, and both broadly rounded (Fig. 2a-c). 

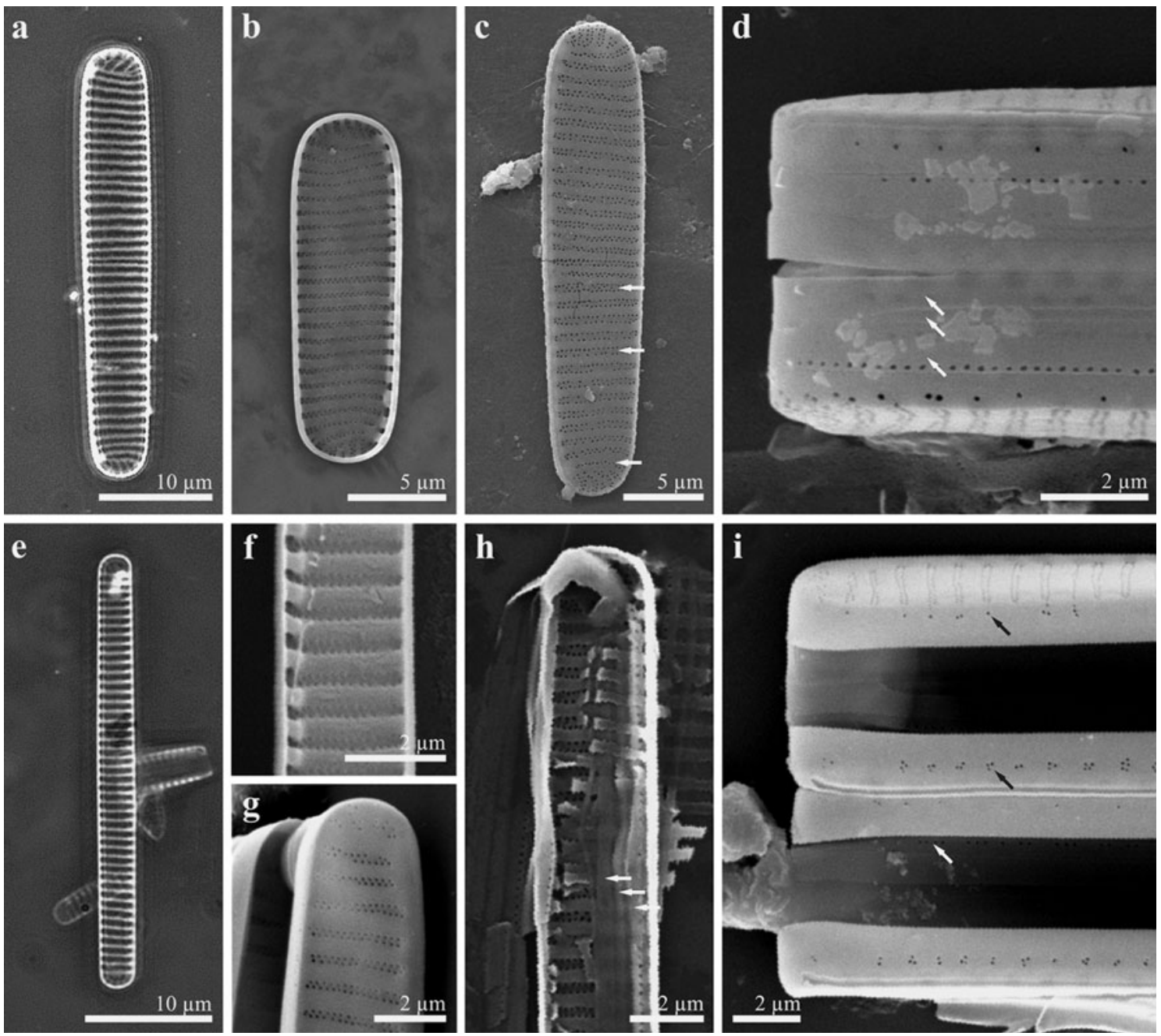

Fig. 2 a-d Fragilariopsis curta. e-i F. cylindrus. a LM Cell in valve view showing the heteropolar transapical axis. b SEM Valve in internal view presenting the pattern of the striae and details of fibulae. c SEM Valve in external view with striae perforated by one, two or three rows of poroids (see arrows). d SEM Part of frustules in girdle view. Note details of the valve mantle and the three bands, valvocopula with one row of poroids and two unperforated copulae (pointed by arrows). e LM Cell in valve view viewing straight parallel

The valve mantle $(\bar{x}=1.0 \mu \mathrm{m})$ is structured like the valve face, with one row of poroids irregularly distributed (Fig. 2d; Table 2). The cingulum is composed by three bands (copulae), the valvocopula $(\bar{x}=1.0 \mu \mathrm{m})$ with one row of poroids close to the advalvar edge and two unperforated copulae (Fig. 2d; Table 2). The first copula in the abvalve direction is narrower $(\bar{x}=0.25 \mu \mathrm{m})$ than the other one $(\bar{x}=0.60 \mu \mathrm{m})$ (Fig. $2 \mathrm{~d})$. The apical axis is $12.5-54.5 \mu \mathrm{m}$; the transapical axis is $4.0-6.5 \mu \mathrm{m}$; and the transapical striae count $10-14$ in $10 \mu \mathrm{m}$ (Table 3). The striae are straight to slightly oblique and curved near the ends. Each of them is usually perforated by two rows of poroids (30-39 in $10 \mu \mathrm{m}$ ); occasionally, one or three rows are also found. At the ends, the rows of poroids become margins and isopolar transapical axis. f, g SEM Part of valves in internal and external view, respectively, showing details of fibulae and striae with two rows of poroids. h SEM Valve and girdle bands, note the three copulae (see arrows). i SEM Part of frustules in girdle view, details of the mantle with one to three poroid high (see black arrows) and three copulae, the valvocopula with one row of poroids (see white arrow)

radiate or perpendicular. The fibulae are regularly spaced and generally occur at the same density as the striae (Fig. 2a-c).

Remarks: Hasle (1965) compared F. curta with other Fragilariopsis species having straight valve margins, such as $F$. cylindrus and $F$. vanheurckii. In our samples, the heteropolarity and the smaller density of poroids present in $F$. curta were the characters used to distinguish it from the other two species. In addition, $F$. curta does not have the central nodule found in $F$. vanheurckii. Our observed morphometric data of $F$. curta differed slightly from published data, particularly by higher upper limits for densities of transapical striae and poroids (Table 3). Frenguelli (1943) mistakenly placed $F$. curta as a 
Table 2 Details of mantle and copulae for Fragilariopsis spp.

\begin{tabular}{llll}
\hline Species & Valve mantle characters & Valvocopula characters & Copulae characters \\
\hline F. curta & One row of poroids & One row of poroids & Two, unperforated \\
F. cylindrus & $\begin{array}{l}\text { One row of poroids or groups of two to five, } \\
\text { different in proximal and distal sides }\end{array}$ & One row of poroids & Two, unperforated \\
F. kerguelensis & Unperforated & With or without one row of poroids & One, unperforated \\
$F$. nana & One row of poroids & One row of poroids & Two, unperforated \\
$F$. obliquecostata & Unperforated & Unperforated & One, unperforated \\
$F$. peragallii & Unperforated & n/d & n/d \\
$F$. pseudonana & Unperforated & One row of poroids & n/d \\
$F$. rhombica & Unperforated & One row of poroids & One, unperforated \\
$F$. ritscheri & One row of poroids or unperforated & Unperforated & One, unperforated \\
$F$. separanda & Unperforated & One row of poroids & One, unperforated \\
$F$. sublinearis & Striated, different in proximal and distal sides & One row of poroids & Two, unperforated \\
$F$. vanheurckii & n/d & n/d & n/d \\
\hline
\end{tabular}

$n / d$ no data

Table 3 Morphometric data for Fragilariopsis spp.

\begin{tabular}{|c|c|c|c|c|c|c|c|c|}
\hline \multirow[t]{2}{*}{ Species } & \multicolumn{2}{|c|}{ Apical axis $(\mu \mathrm{m})$} & \multicolumn{2}{|c|}{ Transapical axis $(\mu \mathrm{m})$} & \multicolumn{2}{|c|}{$\begin{array}{l}\text { Transapical striae in } \\
10 \mu \mathrm{m}\end{array}$} & \multicolumn{2}{|c|}{ Poroids in $10 \mu \mathrm{m}$} \\
\hline & $\begin{array}{l}\text { Other } \\
\text { sources }\end{array}$ & This study & $\begin{array}{l}\text { Other } \\
\text { sources }\end{array}$ & This study & $\begin{array}{l}\text { Other } \\
\text { sources }\end{array}$ & $\begin{array}{l}\text { This } \\
\text { study }\end{array}$ & $\begin{array}{l}\text { Other } \\
\text { sources }\end{array}$ & $\begin{array}{l}\text { This } \\
\text { study }\end{array}$ \\
\hline F. $\operatorname{curta}(n=25)^{\mathrm{b}}$ & $10-42$ & $12.5-\mathbf{5 4 . 5}(26 \pm 10.6)$ & $3.5-6$ & $4-6.5(5.5 \pm 0.6)$ & $9-12$ & 10-14 (12) & $30-33$ & 30-39 (35) \\
\hline F. cylindrus $(n=15)^{\mathrm{a}}$ & $4.5-74$ & $15.5-55(29.5 \pm 11.9)$ & $2.4-4$ & $2.4-4(3 \pm 0.5)$ & $12-18$ & 10-16 (14) & $40-60$ & $50-56(53)$ \\
\hline F. kerguelensis $(n=30)^{\mathrm{a}} /^{\mathrm{b}}$ & $10-76$ & $17-\mathbf{8 3}(44 \pm 16.6)$ & $5-11$ & $5.5-11(8.5 \pm 1.3)$ & $4-7$ & $4-7(6)$ & $8-10$ & 8-14 (10) \\
\hline F. nana $(n=24)^{\mathrm{a}}$ & $2.4-15.5$ & $3-10(5.5 \pm 2)$ & $1.4-2.4$ & $1.5-2.2(2 \pm 0.2)$ & $13.5-20$ & 14-20 (17) & $60-80$ & 54-80 (67) \\
\hline F. obliquecostata $(n=31)^{\mathrm{a}} /^{\mathrm{b}}$ & $57-110$ & 48-125 $(82 \pm 20.7)$ & $8-10$ & $\mathbf{7 - 1 0 . 5}(8.5 \pm 1)$ & $6.5-8$ & 5.5-10 (7) & $21-22$ & 20-32 (24) \\
\hline F. peragallii $(n=2)^{\mathrm{a}}$ & $32-90$ & $47-50$ & $7-8$ & 7.5 & $7-9$ & $7-8$ & ca. 16 & ca. 17 \\
\hline F. pseudonana $(n=16)^{\mathrm{a}}$ & $4-20$ & $4-11(6 \pm 2.3)$ & $3.5-5$ & $2.5-4(3.5 \pm 0.5)$ & $18-22$ & $18-\mathbf{2 3}(20)$ & $60-70$ & 50-67 (59) \\
\hline F. rhombica $(n=32)^{\mathrm{a}}$ & $8-53$ & $8.5-48.5(24 \pm 9.4)$ & $7-13$ & $7-12(10 \pm 1.5)$ & $8-16$ & $9-16(12)$ & $22-26$ & 22-32 (25) \\
\hline F. ritscheri $(n=16)^{\mathrm{b}}$ & $22-57$ & $35-56(44 \pm 6.5)$ & $8-9$ & $8-\mathbf{9 . 5}(9 \pm 0.5)$ & $6-11$ & $6-9(8)$ & $18-24$ & $18-\mathbf{2 8}(23)$ \\
\hline F. separanda $(n=14)^{\mathrm{a}}$ & $10-33$ & $10-\mathbf{3 6}(19 \pm 8.2)$ & $8-13$ & 5.5-12.5 $(9.5 \pm 2.5)$ & $10-14$ & $10-14(12)$ & $12-15$ & $12-20(14)$ \\
\hline F. sublinearis $(n=26)^{\mathrm{a}}$ & $30-92$ & $38-84(61 \pm 13.3)$ & $5.5-6.5$ & 5-6 $(5.5 \pm 0.4)$ & $7.5-9$ & 7.5-10 (9) & $35-39$ & $35-40(39)$ \\
\hline F. vanheurckii $(n=7)^{\mathrm{a}}$ & $35-77$ & $36-79.5(49 \pm 15.7)$ & ca. 5 & 3.9-5.3 $(4.5 \pm 0.4)$ & $10-11$ & 9-12 (11) & $42-51$ & $50-56(53)$ \\
\hline
\end{tabular}

Published data from Hasle (1965), also from Lundholm and Hasle (2008) for F. cylindrus and F. nana and from Scott and Marchant (2005) for number of poroids in $10 \mu \mathrm{m}$ in $F$. peragallii. Average \pm standard deviation in parenthesis. Numbers in bold represent new ranges of data

a Isopolar valve symmetry

b Heteropolar valve symmetry

synonym of $F$. linearis Castracane. Later on, Frenguelli (in Frenguelli 1960, Frenguelli and Orlando 1958, 1959) regarded the species as a new variety, $F$. linearis var. curta. He distinguished it by its smaller valve (length 11-20 $\mu \mathrm{m}$, width 5.0-5.5 $\mu \mathrm{m})$ and more closely spaced striae $(12$ in $10 \mu \mathrm{m})($ Fig. 7a, b). Hasle (1965) considered this variety as a synonym of $F$. curta. By examining Frenguelli's Collection, it was possible to establish that the diagnostic characters chosen by Frenguelli for $F$. linearis var. curta were consistent with the data of $F$. curta obtained from our material. Thus, we agree with
Hasle (1965) in considering this variety as a synonym for F. curta.

$F$. curta was the most frequent (i.e. with a wide distribution) Fragilariopsis species in our study area, present in the three areas (AS, DP and WS), at water temperatures and salinities varying from $-1.60-13.35^{\circ} \mathrm{C}$ and 33.10-34.24 psu, respectively. It was the Fragilariopsis species with the greatest relative abundance in the WS (Table 4). F. curta has previously been reported in the southern cold water region, both in plankton and ice (Hasle and Syvertsen 1997) and in oceanic and neritic waters 


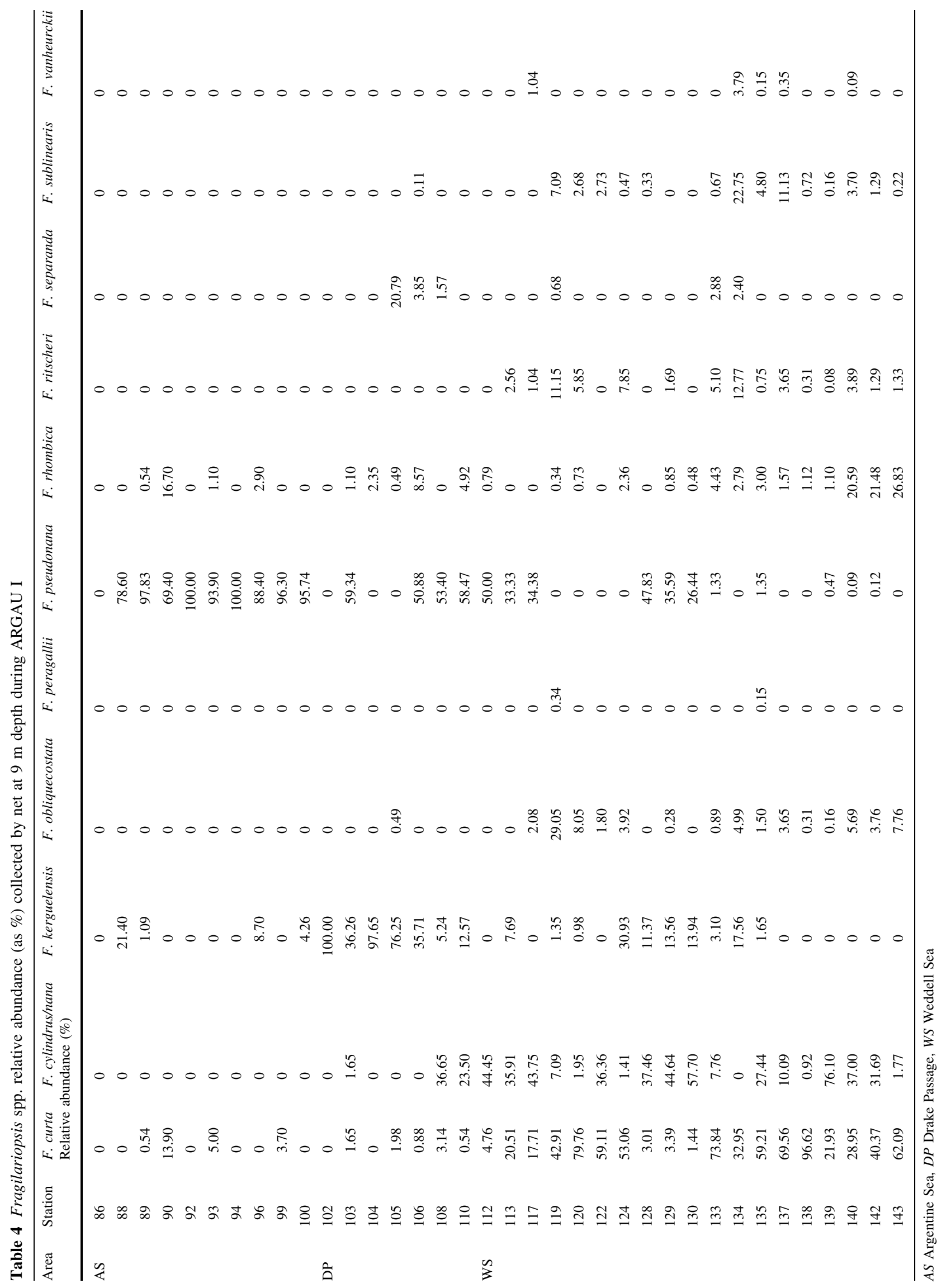


(Manguin 1960). In particular, it is known as one of the most dominating diatom species in the Weddell Sea (Kang and Fryxell 1993; Hegseth and von Quillfeldt 2002). In contrast, it was not abundant at $41^{\circ} 30^{\prime} \mathrm{S}-57^{\circ} 43^{\prime} \mathrm{W}$ in the SW Atlantic Ocean, at a temperature of $5.95^{\circ} \mathrm{C}$ and a salinity of 33.42 psu (Frenguelli and Orlando $1959=$ F. linearis var. curta).

Fragilariopsis cylindrus (Grunow ex Cleve) Frenguelli in Frenguelli and Orlando (Figs. 2e-i, 7c-e)

Frenguelli and Orlando (1958): 107, fig. 19d. Manguin (1960): 298, pl. 12, fig. 127. Hasle (1965): 34-37, pl.12, figs $6-12$; pl. 14, figs $1-10$; pl. 17, figs $2-4$. Lundholm and Hasle (2008): 237-241, figs 1-6, 12-14, 17, 19, 20, 22-23

Basionym: Fragilaria cylindrus Grunow ex Cleve Synonym: Nitzschia cylindrus (Grunow ex Cleve) Hasle

The cells are solitary or joined in short colonies, often in doublets. The valve shape is linear and isopolar with broadly rounded ends (Fig. 2e). The valve mantle $(\bar{x}=1.6 \mu \mathrm{m})$ in the proximal side is perforated by groups of two to five poroids and in the distal side usually by one or two poroids, rarely three, all of these aligned with the striae of the valve face (Fig. 2i; Table 2). The girdle consists of three copulae, a valvocopula $(\bar{x}=0.75 \mu \mathrm{m})$ with one row of poroids close to the advalvar edge, and two unperforated copulae (Fig. 2h, i; Table 2). The apical axis is $15.5-55.0 \mu \mathrm{m}$; the transapical axis is $2.4-4.0 \mu \mathrm{m}$; and the transapical striae count $10-16$ in $10 \mu \mathrm{m}$ (Table 3). The striae are straight and perforated by two, rarely three, rows of poroids (50-56 in $10 \mu \mathrm{m})$. At the ends, the striae become nearly parallel to the apical axis (Fig. 2g). The fibulae occur at approximately the same density as the striae (Fig. 2f).

Remarks: $F$. cylindrus is morphologically similar to F. curta, F. vanheurckii and F. linearis (Hasle 1965; Lundholm and Hasle 2008). Basically, we differentiated $F$. cylindrus from $F$. curta by its isopolar apical axis and from $F$. vanheurckii by the absence of a central nodule (see also $F$. curta and $F$. vanheurckii remarks). Although we did not find $F$. linearis, $F$. cylindrus differs from $F$. linearis by having a smaller size and higher density of striae and poroids (Hasle 1965). The first mention of $F$. cylindrus from Antarctic waters was made by van Heurck (1909) as Fragilaria cylindrus f. elongata. Frenguelli in Frenguelli and Orlando (1958) made the valid transfer to Fragilariopsis (Lundholm and Hasle 2008). Re-analyzing Frenguelli's material using LM, the specimens identified as $F$. cylindrus have a valve length of 5-37 $\mu \mathrm{m}$, a valve width of 1.6-4.0 $\mu \mathrm{m}$ and 14-16 striae in $10 \mu \mathrm{m}$ corresponding to $F$. cylindrus or $F$. nana (Fig. 7c-e). As analysis of Frenguelli's material by EM was not possible, we are unable to give a more precise identification based on the density of poroids in the striae.
Recently, Lundholm and Hasle (2008), using morphological and molecular data of material initially regarded as $F$. cylindrus, revealed and typified two separate species: one being identical to $F$. cylindrus and the other to $F$. nana sensu stricto. The morphological characters that differentiate $F$. cylindrus from $F$. nana sometimes overlap. Nevertheless, the valve width, the poroid density as well as the number of poroid rows per striae can be used to distinguish the two species (Table 3). Because it is not possible to differentiate between these two species using LM, the cell counts are listed as F. cylindrus/nana (see section Phytoplankton composition and abundance).

We found $F$. cylindrus/F. nana in the DP and the WS. It was a Fragilariopsis species found frequently and of high relative abundance in the WS (Table 4), in accordance with previous studies (Kang and Fryxell 1992, 1993). According to Lundholm and Hasle (2008), F. cylindrus, which may include $F$. nana, is a marine planktonic and ice species, present in both the Northern and Southern Hemispheres. Antoniades et al. (2008) also report F. cylindrus as a brackish species, found in ponds adjacent to the ocean (Canada). In the SW Atlantic Ocean, it has been reported from surface sediments (Romero and Hensen 2002). Frenguelli and Orlando (1958) cite $F$. cylindrus as an abundant species in sea ice in the Bellingshausen Sea $\left(67^{\circ} 02^{\prime} \mathrm{S}-72^{\circ} 50^{\prime} \mathrm{W}\right)$. In this study, the species was found at a temperature and salinity range of $-1.60-6.22^{\circ} \mathrm{C}$ and 33.10-34.24 psu, respectively.

\section{Fragilariopsis kerguelensis (O’Meara) Hustedt} (Figs. 3a-h, 7f, g)

Schmidt (1913), pl. 299, figs 9-14. Hustedt (1952): 294. Frenguelli (1960): 20, pl. 2, fig. 7. Cortese and Gersonde (2007): 526-544, fig. 3

\section{Basionym: Terebraria kerguelensis O'Meara}

Synonyms: Fragilaria antarctica Castracane. Fragilariopsis antarctica (Castracane) Hustedt in A. Schmidt. Fragilariopsis antarctica var. elliptica Frenguelli

The frustules are strongly silicified; they are organized in colonies united partly at the valve surface through mucilaginous material; the valve face is slightly curved (Fig. 3a). The valve shape, in the largest specimens, is lanceolate, with rounded ends and principally heteropolar (Fig. 3b, e, $\mathrm{f}$ ), whereas in some of the smaller ones, it is elliptic, isopolar and with more rounded ends (Fig. 3b-d). The valve mantle is unperforated $(\bar{x}=1.10 \mu \mathrm{m})$. The cingulum consists of two bands, the valvocopula $(\bar{x}=2.60 \mu \mathrm{m})$ with or without one row of poroids and an unperforated copula $(\bar{x}=2.00 \mu \mathrm{m})$ (Fig. $3 \mathrm{~g}, \mathrm{~h}$; Table 2). The apical axis is $17-83 \mu \mathrm{m}$; the transapical axis is $5.5-11.0 \mu \mathrm{m}$; and the transapical striae count 4-7 in $10 \mu \mathrm{m}$ (Table 3). The striae are straight to slightly oblique, occasionally curving near 

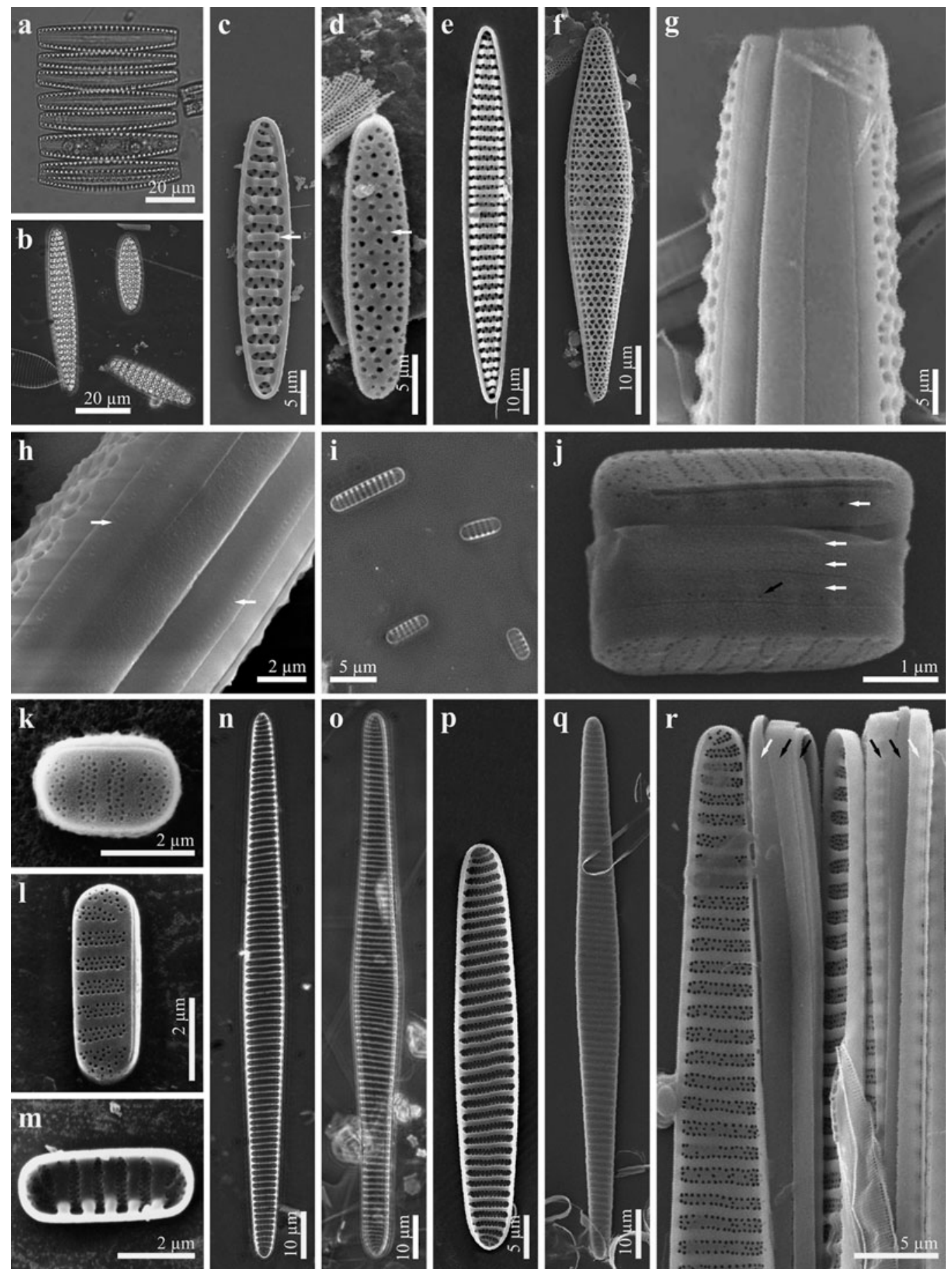

Fig. 3 a-h Fragilariopsis kerguelensis. $\mathbf{i}-\mathbf{m} F$. nana. $\mathbf{n}-\mathbf{r} F$. obliquecostata. a LM Cells in ribbon-like colonies united by part of the valve face and showing the coarse striation. b LM Specimens including different shapes and sizes. c, d SEM Small specimens in internal and external valve view, respectively, showing isopolar and elliptical shape. Note the knob-like irregularities in both of them (see arrows). e, I SEM Large specimens in internal and external valve view, respectively, showing heteropolar and lanceolate shape. Note the straight to slightly oblique striae with two rows of alternating large poroids. g, h SEM Part of frustules in girdle view with details of the valve mantle and copulae, the valvocopula without (g) or with one row of poroids (h see arrows).

i LM Single cells. j SEM Frustules in girdle view showing details of the valve mantle and the three copulae (see white arrows), the valvocopula with one row of poroids (see black arrow). k, I SEM Valves in external view showing the pattern of striae with three rows of poroids. $\mathbf{m}$ SEM Valve in internal view showing details of the fibulae. $\mathbf{n}$ LM Specimen in valve view with narrowly elliptical shape. o, LM Specimen in valve view, with the central part expanded. p, q SEM Valves in internal and external view, respectively, showing the pattern of the striae. $r$ SEM Part of valves showing striae with two or three rows of poroids and unperforated mantle (see white arrow) and cingulum presenting the valvocopula and copula, both unperforated (see black arrow) 
the ends (Fig. 3c, e). The striae are perforated by two rows of alternating large poroids (8-14 in $10 \mu \mathrm{m})$, clearly visible using LM (Fig. 3b). In some specimens, a third incomplete row of poroids can occur close to the valve edge (Fig. 3f, g). The striae are present at the same density as the fibulae. The interstriae penetrate deeply into the valve, occasionally showing knob-like irregularities in the internal and external views (Fig. 3c, d).

Remarks: F. kerguelensis was relatively easy to recognize using LM in valve view and in girdle view, due to its noticeable silicification, poroid size and coarse striation. The analyzed specimens expanded the previously reported ranges of length of the apical axis and poroid density (Table 3).

Frenguelli (1943) retained the name $F$. antarctica for F. kerguelensis, and in addition, Frenguelli (1960) created the variety elliptica for this species on material from Terre Adélie (later rejected by Hasle 1965). He distinguished the new variety by its elliptical shape and its smaller size (the apical axis 16-19 $\mu \mathrm{m}$ and the transapical axis 6-9 $\mu \mathrm{m}$ ). When analyzing Frenguelli's material (Fig. 7f), we found a close correlation between form and valve size and thus agree with Hasle's (1965) conclusions in rejecting the variety. We also verified the material type for $F$. kerguelensis (Fig. $7 \mathrm{~g}$ ).

We found this species in the three studied areas (AS, DP and WS), and it was the Fragilariopsis species of greatest frequency and relative abundance in the DP (Table 4). $F$. kerguelensis is a marine planktonic diatom present in the southern cold water region (Hasle and Syvertsen 1997) and is considered an important contributor in the global silicon cycle of the iron-limited Southern Ocean (Cortese and Gersonde 2007). In the Southwestern Atlantic Ocean, the species has been found to dominate diatom assemblages in both water column and sediments (Romero and Hensen 2002; Olguín et al. 2006). Frenguelli and Orlando $(1959=F$. antarctical $F$. antarctica var. elliptica) reported this species as scarce $\left(41^{\circ} 30^{\prime} \mathrm{S}-56^{\circ} 11^{\prime} \mathrm{W}\right)$ at a temperature close to $9^{\circ} \mathrm{C}$ and salinity of $33.81 \mathrm{psu}$. In our study, the species was found at a water temperature and salinity between -1.33 and $14.06^{\circ} \mathrm{C}$ and 33.17 and 34.19 psu, respectively.

Fragilariopsis nana (Steemann Nielsen) Paasche (Fig. 3i-m)

Manguin (1960): 298, pl. 12, fig. 127. Lundholm and Hasle (2008): 241, figs 7-10, 15, 16, 18, 21.

Basionym: Fragilaria nana Steemann Nielsen

Synonyms: Fragilariopsis cylindrus var. planctonica Helmcke and Krieger. Fragilariopsis cylindrus f. minor Manguin

Cells are solitary or united in short colonies, often in doublets. The valve shape is linear and isopolar with broadly rounded ends (Fig. 3i, k-m). The valve mantle $(\bar{x}=0.52 \mu \mathrm{m})$ is perforated by one irregular row of poroids, more evident on the proximal side. The girdle consists of a wide valvocopula $(\bar{x}=0.40 \mu \mathrm{m})$ with a single row of poroids near the advalvar edge and two narrower copulae (Fig. 3j; Table 2). The apical axis is $3-10 \mu \mathrm{m}$; the transapical axis is $1.5-2.2 \mu \mathrm{m}$; and the transapical striae count $14-20$ in $10 \mu \mathrm{m}$ (Table 3). The striae are straight and are perforated by two or three rows of poroids (54-80 in $10 \mu \mathrm{m})$. Toward the ends, the rows of poroids become radiate or nearly parallel to the apical axis (Fig. 3k, 1). The fibulae are present in the same density as the striae (Fig. $3 \mathrm{~m}$ ).

Remarks: $F$. nana is a marine planktonic and sea ice species in polar and subpolar regions of the Antarctic and the Arctic (Lundholm and Hasle 2008). As mentioned above (see $F$. cylindrus remarks), it could not be differentiated from $F$. cylindrus using LM, and it was identified in our counts as $F$. cylindrus/F. nana.

Fragilariopsis obliquecostata (van Heurck) Heiden in Heiden and Kolbe (Figs. 3n-r, 7h, i)

van Heurck (1909): 25, pl. 3, fig. 38. Heiden and Kolbe (1928): 555. Frenguelli (1943): 241-243, pl. 1, figs 11-15. Frenguelli and Orlando (1958): 108. Hasle (1965): 18-20, pl. 7, figs 2-7

Basionym: Fragilaria obliquecostata van Heurck

Synonyms: Fragilaria obliquecostata f. maxima van Heurck. Nitzschia obliquecostata (van Heurck) Hasle

The valve shape is narrowly elliptical with obtusely rounded ends and is isopolar to slightly heteropolar (Fig. 3n-q). Some larger specimens showed the central part expanded in valve view (Fig. 3o, q). The valve mantle is unperforated $(\bar{x}=1.15 \mu \mathrm{m})$. The cingulum consists of a valvocopula $(\bar{x}=2.05 \mu \mathrm{m})$ and a slightly narrower copula, both unperforated (Fig. 3r; Table 2). The apical axis is $48-125 \mu \mathrm{m}$; the transapical axis is $7.0-10.5 \mu \mathrm{m}$; and the transapical striae count $5.5-10.0$ in $10 \mu \mathrm{m}$ (Table 3). The striae are oblique, particularly in the middle part, and curved at the ends. They are perforated by two or three rows of poroids $(20-32$ in $10 \mu \mathrm{m})$, and the third, when present, is irregular and/or incomplete (Fig. 3r). The fibulae are present in the same density as the striae.

Remarks: $F$. obliquecostata is morphologically similar to $F$. ritscheri and $F$. sublinearis. According to Hasle (1965), F. obliquecostata can be distinguished from these related species by the presence of oblique transapical striae and a central valve expansion, which seems to be unique within the genus. In particular, Hasle remarks that the smaller specimens of $F$. obliquecostata and the larger ones of $F$. ritscheri are very similar, making it almost impossible to decide between the two. In our samples, we observed oblique striae in both $F$. ritscheri and $F$. sublinearis; we also found some $F$. obliquecostata specimens without a central expansion (Fig. 3n, p). We identified 
F. obliquecostata primarily by the central expansion in the valve (when present), and additionally by its narrowly elliptical valve outline, with both ends obtusely rounded. We differentiated from $F$. ritscheri by $F$. obliquecostata having a narrower valve shape and less evident heteropolarity. F. sublinearis was differentiated due to $F$. obliquecostata having a lower density of poroids, and in the girdle view, by the absence of poroids on the valve mantle and a lower number of copulae (Table 2). The analyzed specimens expanded the previously reported ranges of poroid and stria density (Table 3).

The close relationship between $F$. obliquecostata and $F$. sublinearis led some authors to consider $F$. obliquecostata as a synonym of $F$. sublinearis. Frenguelli (1943) designated Fragilaria obliquecostata van Heurck and Fragilariopsis obliquecostata f. maxima (van Heurck) Heiden-Kolbe as synonyms of $F$. sublinearis. Among the diagnostic characters he used were the extension of the middle part of the valve and the length of apical axis. Later on, Frenguelli and Orlando (1958) considered $F$. obliquecostata f. maxima a valid taxon. By examining Frenguelli's samples from South Orkney Islands and from Esperanza Bay $\left(63^{\circ} 23^{\prime} \mathrm{S}-\right.$ $\left.56^{\circ} 58^{\prime} \mathrm{W}\right)$, we corroborated that all the specimens analyzed by Frenguelli corresponded to $F$. obliquecostata (Fig. 7h, i).

We found $F$. obliquecostata occurring in low relative abundance in comparison to other Fragilariopsis species. In the DP, it was present only in one station, while in the WS it was frequently observed, with its highest contribution to total relative abundance in the northern area (29.05\%, Table 4). Hasle (1965) observed this species in samples from the vicinity of the sea ice or in the ice. In our samples, $F$. obliquecostata was found at temperatures between -1.60 and $3.41^{\circ} \mathrm{C}$ and salinities from 33.10 to $34.24 \mathrm{psu}$. Other studies found it at $63^{\circ} 23^{\prime} \mathrm{S}-56^{\circ} 58^{\prime} \mathrm{W}$ (Esperanza Bay) at water temperatures between 0 and $1^{\circ} \mathrm{C}$ (Frenguelli and Orlando $1958=F$. obliquecostata $\mathrm{f}$. maxima).

Fragilariopsis peragallii (Hasle) Cremer in Cremer et al. (Fig. 4a-d)

Peragallo (1921): 66, pl. 3, fig. 21. Hasle (1965): 41, 42, pl. 9, figs 11, 12; pl. 15, figs 1-5. Cremer et al. (2003): 102, figs 79, 80. Scott and Marchant (2005): 192

Basionym: Nitzschia peragallii Hasle

Synonym: Nitzschia barbieri var. latestriata Peragallo

The valve shape is linear and isopolar, with more or less pointed ends (Fig. 4a, b). Only one specimen was analyzed by SEM. The valve mantle is unperforated $(1.00 \mu \mathrm{m})$ (Fig. 4c, d; Table 2). The apical axis is $47-50 \mu \mathrm{m}$; the transapical axis is $7.5 \mu \mathrm{m}$; and the transapical striae count $7-8$ in $10 \mu \mathrm{m}$ (Table 3). The striae are straight, curved toward the ends; each of them contains two rows of poroids (ca. 17 in $10 \mu \mathrm{m}$ ), which can become incomplete or irregular toward the center of the valve (Fig. 4b-d).

Remarks: $F$. peragallii was established by Hasle in 1965 as Nitzschia peragallii; she compared the morphologic characters of this species with those of Nitzschia barbieri, indicating that both were observed only as single cells. Medlin and Sims (1993) refer to Hasle's (1965) observations and add that although solitary, the two species have the same valve structure as other Fragilariopsis. Later on, Cremer in Cremer et al. (2003) transferred N. peragallii to the genus Fragilariopsis, not having argued that transfer in any way. The present study represents the first EM description of $F$. peragallii.

In this study, $F$. peragallii was the least frequent and least abundant Fragilariopsis species. It was restricted to slope waters of the WS (Table 4) at temperatures between -1.33 and $-1.15^{\circ} \mathrm{C}$ and salinities from 33.17 to $33.33 \mathrm{psu}$. $F$. peragallii is described as a marine species, in both plankton and sea ice, present in the southern cold water region (Cremer et al. 2003). F. peragallii is apparently rare, and it has been reported only a few times since the original description (Scott and Marchant 2005).

\section{Fragilariopsis pseudonana (Hasle) Hasle (Fig. 4e-i)}

Hasle (1965): 22-24, pl. 1, figs 7-14; pl. 4, figs 20, 21; pl. 8, figs 1-9; pl. 17, fig. 6. Hasle (1974): 427. Hasle (1993): 317

Basionym: Nitzschia pseudonana Hasle

Synonym: Fragilariopsis nana (Steemann Nielsen) Paasche

The frustules are lightly silicified and weakly structured; cells are solitary or united into short colonies. The valve shape is lanceolate to elliptical, isopolar and with rounded ends (Fig. 4e, f). The valve mantle is unperforated (Fig. 4g), and the valvocopula has one row of perforations (Fig. 4h; Table 2). The apical axis is $4-11 \mu \mathrm{m}$; the transapical axis is $2.5-4.0 \mu \mathrm{m}$; and the transapical striae count 18-23 in $10 \mu \mathrm{m}$ (Table 3). The striae are straight, curved toward the ends; each of them is perforated by two irregular and/or incomplete rows of small poroids (50-67 in $10 \mu \mathrm{m})$ (Fig. 4f, h). Observation by TEM showed that the poroid hymens are perforated by tiny pores in a concentric pattern (Fig. 4i). The fibulae are present in the same density as the striae (Fig. 4g, h).

Remarks: Hasle (1965) suggested that in the Subantarctic and Antarctic Zones, F. pseudonana has possibly been reported as dwarf forms of $F$. kerguelensis and $F$. rhombica. In our material, we recognized morphological similarities between small specimens of $F$. kerguelensis, $F$. rhombica and also $F$. separanda with $F$. pseudonana. We identified, however, $F$. pseudonana by the more lightly silicified valve and the higher density of striae and poroids. Our material 

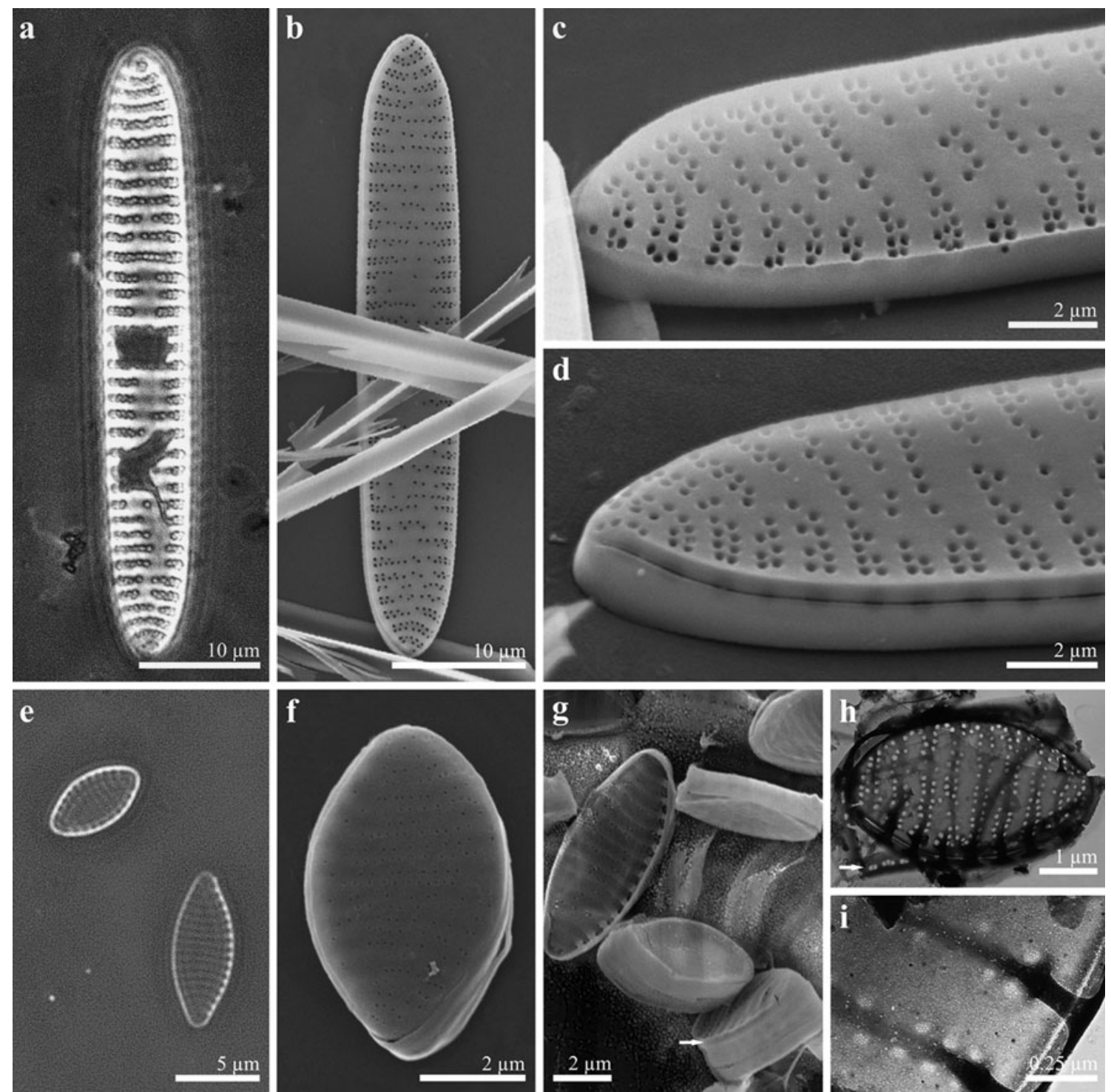

Fig. 4 a-d Fragilariopsis peragallii. e-i $F$. pseudonana. a LM Specimen in valve view showing the linear and isopolar shape. b SEM Valve in external view with two rows of poroids becoming incomplete or irregular toward the center. c, d SEM Part of valves with ends more or less pointed and unperforated valve mantle (same

valve in both figures, rotated $180^{\circ}$ ). e LM General view of valves. f SEM Frustule in external view. g SEM Valve in internal view and different frustules, note the unperforated valve mantle (see arrow). h TEM Valve showing details of the valvocopula, fibulae and striae with two rows of poroids. i, TEM Details of the poroid hymens

differed from the descriptions of $F$. pseudonana in the literature by having a shorter transapical axis and a smaller number of poroids in $10 \mu \mathrm{m}$ (Table 3 ).

We found $F$. pseudonana in all three studied areas (AS, DP and WS) and thus report $F$. pseudonana for the first time in Argentine shelf waters. Furthermore, F. pseudonana was the Fragilariopsis species of the greatest relative abundance in the AS, in the south-east DP and in open waters of the WS, in particular at station 128. It was also the most frequent Fragilariopsis species in the AS (Table 4). In the first two areas, it appeared both viable and dead in irregular gelatinous masses of unknown origin. $F$. pseudonana has been reported as a marine planktonic species with

cosmopolitan distribution (Hasle and Syvertsen 1997). Apparently, this species can tolerate a very wide range of temperatures, being cosmopolitan and present from the Arctic to Antarctica (Hasle 1965). In surface sediments of the Southwestern Atlantic Ocean, it was reported at $31^{\circ} 53^{\prime} \mathrm{S}-51^{\circ} 41^{\prime} \mathrm{W}$ by Romero and Hensen (2002). Other studies have found that together with $F$. cylindrus, $F$. pseudonana was the dominant nanoplanktonic diatom during the summers of 1990 and 1991 in NW of Elephant Island, at $60-61^{\circ} \mathrm{S}$ and $55-57^{\circ} \mathrm{W}$ (Villafañe et al. 1995). Their abundance was interpreted in relation to the dominance of small cells in iron-deficient waters. Similarly, Kang and Lee (1995) found F. pseudonana as the most 

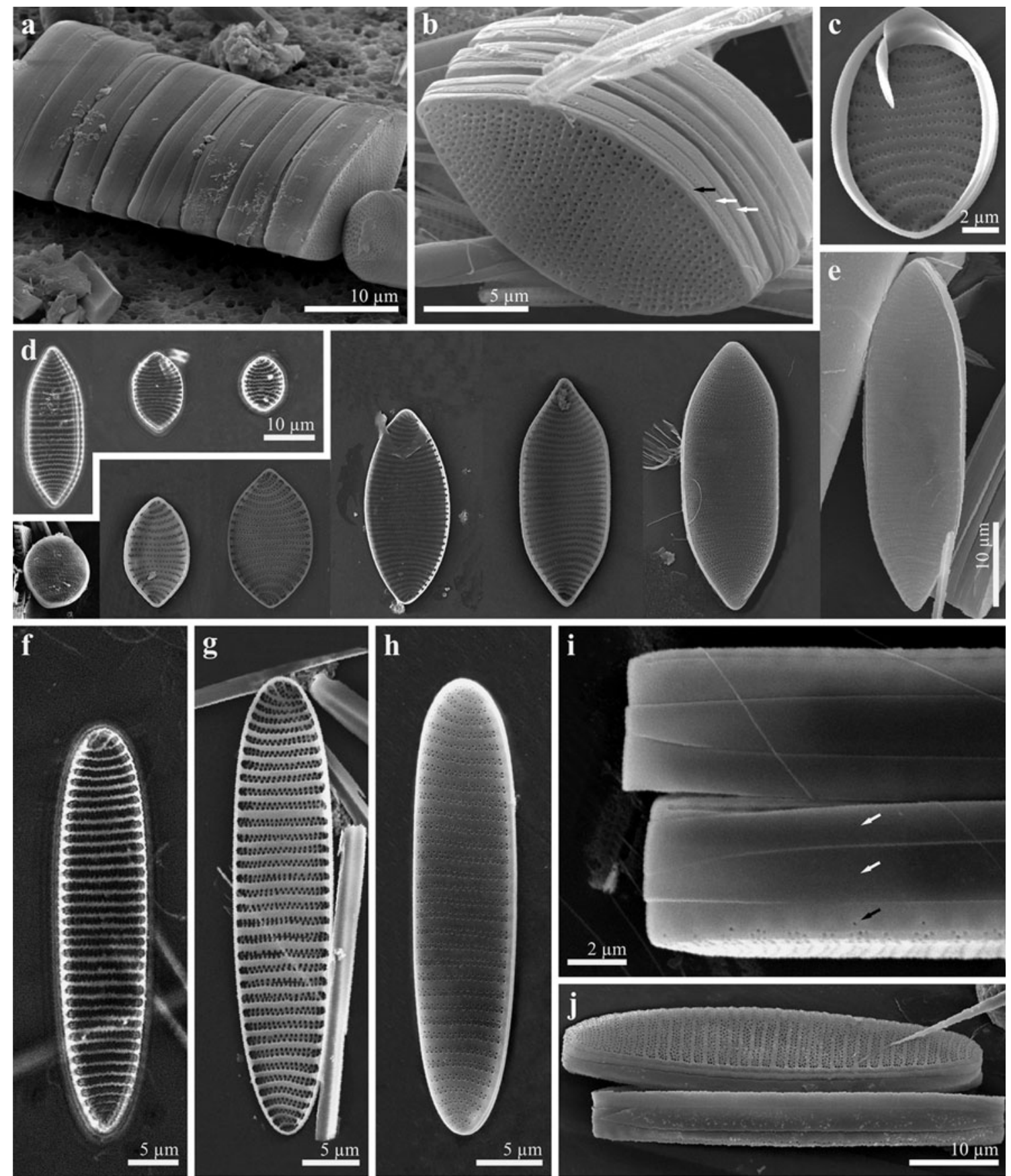

Fig. 5 a-e Fragilariopsis rhombica. $\mathbf{f}-\mathbf{j} F$. ritscheri. a, b SEM Cells in ribbon-shaped colonies united by of the valve face showing the mantle (see black arrow) and copulae (see white arrows). c SEM Valve in internal view. d LM and e SEM Specimens showing morphometric variability with a trend from subcircular to broadly lanceolate. f ML Specimen in valve view showing the heteropolar transapical axis. g, h SEM Valves in internal and external view, respectively, showing the pattern of the striae and fibulae. i SEM Part of frustules in girdle view, details of the mantle with occasional row of poroids (see black arrow), valvocopula and copula both unperforated (see white arrows). $\mathbf{j}$ SEM Specimens in valve and girdle view, note the striae perforated by three rows of poroids important carbon contributor among the diatoms in waters of the DP during the summer, approximately at $62^{\circ} \mathrm{S}$ and $62^{\circ} \mathrm{W}$. In our samples, F. pseudonana was associated with water temperatures between -1.33 and $14.06^{\circ} \mathrm{C}$ and salinities from 33.33 to 34.24 psu.
Fragilariopsis rhombica (O'Meara) Hustedt (Fig. 5a-e)

O’Meara (1877): 55, pl. 1, fig. 2. Hustedt (1952): 296, figs 6, 7. Hasle (1965): 24-26, pl. 1, fig. 6; pl. 4, fig. 19; pl. 6, fig. 5; pl. 8, fig. 11; pl. 9, figs 1-6; pl. 10, figs 2-6 
Basionym: Diatoma rhombicum O’Meara

Synonym: Nitzschia angulata Hasle

The frustules are arranged in ribbon chains (Fig. 5a). The valve shape is subcircular to broadly lanceolate, isopolar and with pointed ends. The larger specimens have straight parallel margins reduced toward the pointed ends (Fig. 5d, e). The valve mantle is unperforated $(\bar{x}=1.10 \mu \mathrm{m})$. The cingulum consists of a valvocopula $(\bar{x}=1.45 \mu \mathrm{m})$, with one row of small perforations close to the advalvar edge, and an unperforated and slightly narrower copula $(\bar{x}=1.30 \mu \mathrm{m})$ (Fig. 5b; Table 2). The apical axis is $8.5-48.5 \mu \mathrm{m}$; the transapical axis is $7-12 \mu \mathrm{m}$; and the transapical striae count 9-16 in $10 \mu \mathrm{m}$ (Table 3). The external valve surface has knob-like irregularities (difficult to see in Fig. 5b, similar to a granulated surface). The pattern of the striae is straight in the middle part of the valve and curved toward the ends. The striae are perforated by two rows of alternating poroids (22-32 in $10 \mu \mathrm{m})$. Sometimes, mainly in the smallest specimens, the striae are biseriate near the edges, and they become uniseriate toward the center of the valve (Fig. 5c,e). The fibulae are present in the same density as the striae (Fig. 5e).

Remarks: The valves of $F$. rhombica and $F$. separanda have very similar morphology. According to Hustedt (1958), the valve shape of $F$. rhombica is lanceolate to linear and $F$. separanda is mainly linear. After examination of several specimens of each species, we could not corroborate this difference. $F$. rhombica generally has biseriate striae, whereas $F$. separanda has uniseriate striae. In addition, the former has smaller and denser poroids. Some specimens of $F$. rhombica had a higher density of poroids than in the literature (Table 3).

We found this species in all three studied areas (AS, DP and WS). It was one of the most frequent species in the DP and in the WS. The greatest relative abundance ( $\sim 20-27 \%$ ) was found in the southern WS, near the coast (Table 4). According to Hasle and Syvertsen (1997), it is found in the southern cold water region. In the SW Atlantic Ocean $\left(35^{\circ} 58^{\prime} \mathrm{S}-52^{\circ} 26^{\prime} \mathrm{W}\right)$, Frenguelli and Orlando (1959) reported $F$. rhombica as "uncommon" at temperatures close to $4^{\circ} \mathrm{C}$ and at a salinity of $35.7 \mathrm{psu}$. In our samples, this species was found at a water temperature of $-1.60-13.35^{\circ} \mathrm{C}$ and at a salinity of 33.17-34.24 psu.

\section{Fragilariopsis ritscheri Hustedt (Fig. 5f-j)}

Hustedt (1958): 164, pl. 11, figs 133-136; pl. 12, fig. 153. Hasle (1965): 20, 21, pl. 1, fig. 20; pl. 3, fig. 3; pl. 4, figs 1-10; pl. 5, figs 12, 13; pl. 6, fig. 1; pl. 7, fig. 8. Hasle (1972): 115. Scott and Marchant (2005): 182-184, fig. 2.105a-d.

Synonym: Nitzschia ritscheri (Hustedt) Hasle
The valve shape is principally elliptical and heteropolar, with one end more rounded than the other (Fig. $5 \mathrm{f}-\mathrm{h}$ ); sometimes the valve margins are almost straight in the middle part of the valve (Fig. 5h). The valve mantle $(\bar{x}=1.10 \mu \mathrm{m})$ is unperforated; occasionally, it can present one irregular row of poroids aligned with the striae of the valve surface (Fig. 5i; Table 2). The cingulum consists of a valvocopula $(\bar{x}=2.30 \mu \mathrm{m})$ and a narrower copula $(\bar{x}=1.65 \mu \mathrm{m})$, both unperforated (Fig. 5i, j; Table 2). The apical axis is 35-56 $\mu \mathrm{m}$; the transapical axis is 8.0-9.5 $\mu \mathrm{m}$; and the transapical striae count 6-9 in $10 \mu \mathrm{m}$ (Table 3). The striae are straight or slightly oblique, curved toward the ends (Fig. 5g, h). The striae are perforated by two or, more rarely, three rows of poroids (18-28 in $10 \mu \mathrm{m})$; the third, when present, is incomplete. The fibulae are present in the same density as the striae (Fig. $5 \mathrm{~g}$ ).

Remarks: Hasle (1965) compared F. ritscheri with other Fragilariopsis species, finding $F$. kerguelensis and $F$. obliquecostata to be the most closely related species. We resorted to the finer valve structure and the higher density of poroids in $F$. ritscheri to differentiate it from $F$. kerguelensis (see also $F$. obliquecostata remarks). Our analysis expanded the previously reported range of poroid density (Table 3).

We only found $F$. ritscheri in the WS and at low relative abundance compared to the other Fragilariopsis species. It was, however, one of the five most frequent species in this area (Table 4). F. ritscheri has been reported as a marine planktonic diatom restricted to the southern cold water region (Hasle and Syvertsen 1997). Romero and Hensen (2002) reported this species in high concentration in surface sediments of the Southwestern Atlantic Ocean at $37^{\circ} 53^{\prime} \mathrm{S}-51^{\circ} 41^{\prime} \mathrm{W}$ and at $47^{\circ} 96^{\prime} \mathrm{S}-56^{\circ} 18^{\prime} \mathrm{W}$. Moreover, it was observed as one of the dominating species during a peak in chlorophyll $a$ concentration recorded in this area $\left(37^{\circ} 15^{\prime} \mathrm{S}-51^{\circ} 23^{\prime} \mathrm{W}\right.$, Olguín et al. 2006). In our samples, $F$. ritscheri was associated with water temperature and salinity ranges of -1.60 to $-0.09^{\circ} \mathrm{C}$ and $33.17-34.24 \mathrm{psu}$, respectively.

\section{Fragilariopsis separanda Hustedt (Fig. 6a-d)}

Hustedt (1958): 165, pl. 10, figs 108-112. Hasle (1965): 26, 27, pl. 9, figs 7-10; pl. 10, fig. 1. Hasle (1993): 317. Scott and Marchant (2005): 184

Synonym: Nitzschia separanda (Hustedt) Hasle

The frustules are arranged in ribbon chains (Fig. 6a). The valve shape is elliptical to broadly lanceolate, isopolar and with pointed ends (Fig. 6b, c). In the larger specimens, the margins are principally straight and parallel in the middle part of the valve (Fig. 6b). The valve mantle is unperforated. The cingulum consists of a valvocopula with one row of small poroids and a copula without 

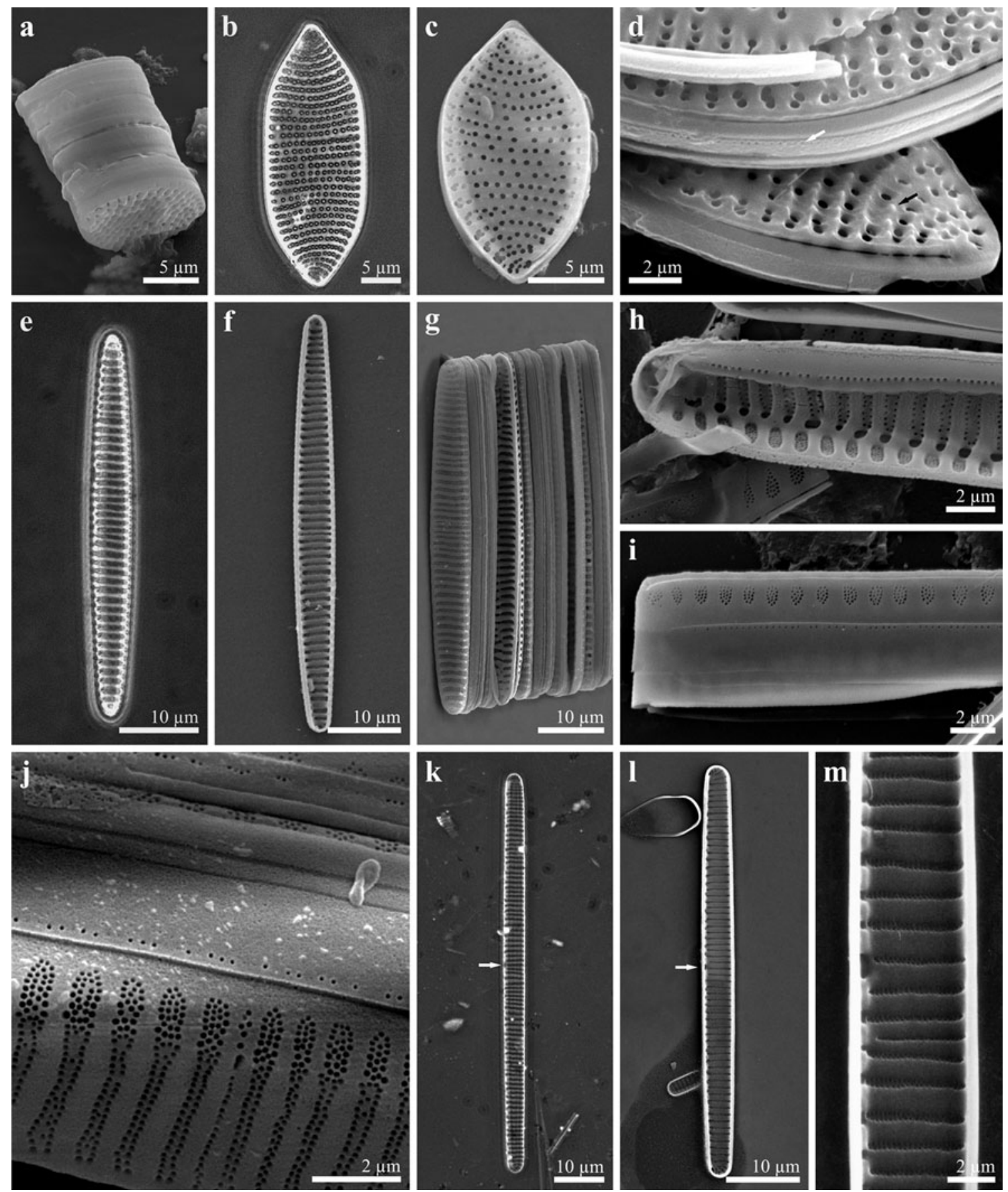

Fig. 6 a-d Fragilariopsis separanda. $\mathbf{e}-\mathbf{j} \quad F$. sublinearis. $\mathbf{k}-\mathbf{m}$ F. vanheurckii. a SEM Cells in ribbon-shaped colonies. b, c LM and SEM, respectively, valves showing the pattern of the striae constituted by large poroids. d SEM Part of valves presenting details of the unperforated mantle and the copulae, the valvocopula with one row of small poroids (see white arrow). Note knob-like irregularities (see black arrow) in the external valve surface. e, f LM and SEM, respectively, specimens in valve view. g SEM Cells in ribbon-shaped

colonies. h SEM Part of the valve showing the mantle (internal view) and valvocopula. i SEM Detail of the mantle (external view) positioned in the proximal side. $\mathbf{j}$ SEM Detail of the mantle (external view) positioned in the distal side, the copulae and pattern of the striae. k, l LM and SEM, respectively, both valves in internal view showing the central nodule (see arrows). m SEM Part of the valve illustrating pattern of the striae and fibulae

perforations (Fig. 6d; Table 2). The apical axis is $10-36 \mu \mathrm{m}$; the transapical axis is $5.5-12.5 \mu \mathrm{m}$; and the transapical striae count $10-14$ in $10 \mu \mathrm{m}$ (Table 3). The external valve surface shows knob-like irregularities

(Fig. 6d). The striae are straight in the middle part of the valve and curved toward the ends; they are perforated by one row of large poroids (12-20 in $10 \mu \mathrm{m}$ ), clearly visible using LM (Fig. 6b). Some specimens showed striae with 
one additional incomplete row of poroids close to the valve edge (Fig. $6 c$, d). The fibulae are present in the same density as the striae.

Remarks: According to Hasle (1965), F. separanda has possibly been misidentified as $F$. rhombica in investigations into the Southern Ocean. We recognized F. separanda by the presence of uniseriate striae with a lower density of poroids (see also $F$. rhombica remarks). The morphometric data of our specimens differed from previous reports with respect to the length of the transapical axis and the density of poroids (Table 3 ).

We found $F$. separanda in two of the studied areas, DP and WS. The relative abundance was high $(20.79 \%)$ in the middle of the DP (station 105). In the WS, it was one of the Fragilariopsis species with low frequency. F. separanda is a marine planktonic diatom present in the southern cold water region (Hasle and Syvertsen 1997). This species was present in surface sediments of the Southwestern Atlantic Ocean between $32^{\circ} 30^{\prime} \mathrm{S}-41^{\circ} 26^{\prime} \mathrm{W}$ and $47^{\circ} 96^{\prime} \mathrm{S}-56^{\circ} 18^{\prime} \mathrm{W}$ (Romero and Hensen 2002). In continental shelf waters of the Argentine Sea, it was found only from $39^{\circ} 05^{\prime} \mathrm{S}-$ $55^{\circ} 43^{\prime} \mathrm{W}$ to $39^{\circ} 23^{\prime} \mathrm{S}-55^{\circ} 11^{\prime} \mathrm{W}$, associated with temperatures between 6.2 and $8.3^{\circ} \mathrm{C}$ and salinities from 33.9 to 34.08 psu (Lange $1985=$ Nitzschia aff. separanda). In this study, F. separanda was found at water temperatures and salinities varying from -1.15 to $4.33^{\circ} \mathrm{C}$ and 33.17 to 33.89 psu, respectively.

Fragilariopsis sublinearis (van Heurck) Heiden in Heiden and Kolbe (Fig. 6e-j)

van Heurck (1909): 25, pl. 3, fig. 39. Heiden and Kolbe (1928): 554. Hasle (1965): 27-30, pl. 7, fig. 1; pl. 11, figs 1-10; pl. 12, fig. 1; pl. 17, fig. 1

Basionym: Fragilaria sublinearis van Heurck

Synonym: Nitzschia sublineata Hasle

The valve shape is sublinear, narrow and isopolar, with rounded ends (Fig. 6e-g). The valve mantle is wide $(\bar{x}=2.0 \mu \mathrm{m})$ and is perforated by numerous poroids (striated); those in the proximal side are arranged in a drop shape (Fig. 6h, i; Table 2). In the distal side, the mantle valve is structured like the valve face (6-8 poroids high and 3-4 poroids wide) (Fig. 6j). The cingulum is composed of three copulae, the valvocopula $(\bar{x}=2.0 \mu \mathrm{m})$, which has one row of small poroids close to the advalvar edge, and two unperforated narrower copulae $(\bar{x}=0.55$ and $1.00 \mu \mathrm{m})$, the middle being the narrower of the three (Fig. 6i,j; Table 2). The apical axis is 38-84 $\mu \mathrm{m}$; the transapical axis is 5-6 $\mu \mathrm{m}$; and the transapical striae count 7.5-10 in $10 \mu \mathrm{m}$ (Table 3 ). The striae are straight, sometimes slightly oblique; they are perforated by two rows of poroids (35-40 in $10 \mu \mathrm{m}$ ), and between these, a few additional poroids can be seen (Fig. 6j). The fibulae are present in the same density as the striae (Fig. 6h).
Remarks: $F$. sublinearis can be confused with $F$. obliquecostata; these two species have morphological features in common. We identified $F$. sublinearis by the arrangement of the poroids in the mantle and by the number of copulae and the density of poroids (Tables 2, 3 ) (see also $F$. obliquecostata remarks). On the other hand, the valve mantle in $F$. sublinearis is similar to the one in $F$. oceanica, which is striated (the latter not included in the present work; showed in Hasle 1964 pl. 4, fig. 9; pl. 6, fig. 5 and Hasle 1965 pl. 2, fig. 9; pl. 3, fig. 2 ; pl. 16, figs 1.2). However, $F$. sublinearis has a valvocopula with a row of small poroids and two unperforated copulae, while $F$. oceanica has all striated copulae (Table 2).

We found this species in the DP and in neritic and oceanic samples from the WS. It made up a small percentage of the Fragilariopsis species; except in open waters of the WS (station 134) where its contribution represented around 23\% (Table 4). F. sublinearis is an Antarctic species characterized as a neritic planktonic and sea ice form (Frenguelli and Orlando 1959; Hasle and Medlin 1990). In this study, F. sublinearis was found at water temperatures between -1.60 and $4.33^{\circ} \mathrm{C}$ and salinities from 33.10-34.24 psu.

\section{Fragilariopsis vanheurckii (Peragallo) Hustedt (Fig. 6 k-m)}

Peragallo (1921): 68, pl. 3, fig. 9. Hustedt (1958): 166, pl. 12, figs 154-156. Frenguelli (1943): 244, 245, pl. 1, fig. 16. Hasle (1965): 30, 31, pl.12, figs 13-16; pl. 13, figs 7 , 8 ; pl. 15 , fig. 8

Basionym: Fragilaria vanheurckii Peragallo

Synonyms: Nitzschia vanheurckii (Peragallo) Hasle. Fragilariopsis linearis Castracane

Only solitary cells were found in our samples. The valve shape is linear and isopolar with rounded ends (Fig. 6k, 1). The apical axis is $36.0-79.5 \mu \mathrm{m}$; the transapical axis is 3.9-5.3 $\mu \mathrm{m}$; and the transapical striae count 9-12 in $10 \mu \mathrm{m}$ (Table 3). The striae are straight, becoming radiated at the ends (Fig. 61). They are perforated by two rows of small poroids $(50-56$ in $10 \mu \mathrm{m})$. The fibulae occur at a slightly lower density than the striae (Fig. $6 \mathrm{~m}$ ). The raphe slit is interrupted in the middle by a central nodule, and this corresponds to a wide central interspace, hardly discernible using LM (Fig. 6k).

Remarks: Frenguelli (1943) designated $F$. vanheurckii (= Fragilaria Van Heurckii) as a synonym of $F$. linearis. This change was later rejected by Hasle (1965). F. vanheurckii is easy to confuse with $F$. cylindrus, but it is distinguished from the latter mainly by its central nodule (see also $F$. curta and $F$. cylindrus remarks). The morphometric data in our material differed slightly from the literature (Table 3). 
We found $F$. vanheurckii only in the WS, and it represented a small fraction of the Fragilariopsis species (Table 4). According to Hasle (1965), F. vanheurckii was present near the Antarctic continent, and it was abundant in brownish under-surface sea ice. She considered that perhaps it is a benthic rather than a planktonic species. The low frequency could thus be explained by the type of sampling carried out here. In our study, this species was found at water temperature and salinity ranges of -1.60 to $-0.17^{\circ} \mathrm{C}$ and $33.33-33.92 \mathrm{psu}$, respectively.

\section{Phytoplankton composition and abundance}

The composition and abundance of total phytoplankton, with emphasis on the Fragilariopsis genus, were analyzed in the three studied areas of the Argentine Sea, the Drake Passage and the Weddell Sea (AS, DP and WS). In the AS, all stations were numerically dominated by unidentified small phytoflagellates $\leq 5 \mu \mathrm{m}\left(\bar{x}=1,771,090\right.$ cells $\left.1^{-1}\right)$. Other flagellates such as cryptophytes were also important but found in lower concentration $\left(\bar{x}=95,403\right.$ cells $\left.1^{-1}\right)$. In this area, the diatom density was very low $\left(\bar{x}=14,965\right.$ cells $\left.1^{-1}\right)$ and consisted mainly of small centric diatoms such as Thalassiosira spp. Fragilariopsis was only found at $48^{\circ} \mathrm{S}$ over the continental shelf (station 90), where F. pseudonana was the dominant diatom $\left(109,375\right.$ cells $1^{-1}$; Table 5). This represented the first finding of $F$. pseudonana in Argentine shelf waters.

Throughout the DP, phytoplankton was also numerically dominated by small phytoflagellates, although at a lower

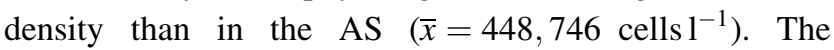
exception was toward the south-east of the DP, in waters presumed under the influence of the NE extension of the Antarctic Peninsula (station 108), where diatoms such as Chaetoceros and Pseudo-nitzschia spp. (672,619 and 130,952 cells $1^{-1}$, respectively) were the more abundant taxa. In this same area, Ferrario and Licea (2006) recorded high summer concentration of Pseudo-nitzschia heimii Manguin. Another diatom in relatively high concentrations at this station was Ceratoneis closterium Ehrenberg $(45,635$ cells $1^{-1}$ ). Cryptophytes were found in low abundance, except in the south-east of the DP (stations 106 and 110), with densities of 66,667 and 100,000 cells $1^{-1}$, respectively. Unidentified dinoflagellates were found at all stations $\left(\bar{x}=71,251\right.$ cells $\left.1^{-1}\right)$ reaching a maximum peak $(358,333$ cells $1^{-1}$ ) at station 106 . In general, total phytoplankton abundance increased from the Polar Front $\left(\sim 57^{\circ} \mathrm{S}\right.$, stations 104-105) toward the south-east (Table 5).

The genus Fragilariopsis showed an average concentration of 33,560 cells $1^{-1}$ in the DP, representing 4.33 and $15.60 \%$ of total phytoplankton and diatom density, respectively. The highest Fragilariopsis contribution to total phytoplankton and diatom density was found south of the Polar Front (station 105; 14.94 and 87.80\%, respectively); F. kerguelensis reached a concentration of 21,875 cells $1^{-1}$ and $F$. separanda a concentration of 15,625 cells $1^{-1}$. However, the highest Fragilariopsis density was found further south (station 106) with 100,000 F. kerguelensis cells $1^{-1}$ (Table 5). According to Zielinski and Gersonde (1997), F. kerguelensis is an open ocean species, dominating diatom assemblages in the Antarctic Circumpolar Current between the sea ice edge and the Subtropical Front. Ferrario and Licea (2006) also reported Fragilariopsis as one of the most prominent diatom taxa in this same area during summer and autumn.

In the oceanic waters of the north and east WS (stations 112-135), small phytoflagellates were also the numerically dominant group $\left(\bar{x}=353,504\right.$ cells $\left.1^{-1}\right)$, although in lower density than in the AS and DP. Average diatom concentration was lower than for phytoflagellates $(\bar{x}=110$,

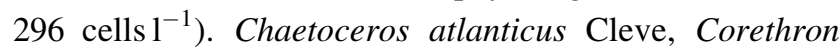
pennatum (Grunow) Ostenfeld, Ceratoneis closterium, Dactyliosolen antarcticus Castracane, Fragilariopsis spp., Pseudo-nitzschia spp. and unidentified centric diatoms were the most prominent taxa among diatoms. Prymnesiophytes were also dominant toward the southern WS, in the proximity of shelf waters (station 137; Phaeocystis sp. 405,556 cells $1^{-1}$ ). Further south, diatoms became dominant in neritic waters. Particularly, between stations 139 and 143, we found an exceptional $D$. antarcticus bloom $\left(\bar{x}=6,111,111\right.$ cells $\left.1^{-1}\right)$. Other abundant diatom taxa were Ceratoneis closterium, Chaetoceros atlanticus, Fragilariopsis spp., Nitzschia longissima (Brébisson in Kützing) Ralfs and Pseudo-nitzschia spp. In contrast to our results, Almandoz et al. (2008) found a greater dominance of small flagellates in neritic waters of the WS. On the other hand, Estrada and Delgado (1990) also found diatoms to be an important component of the summer phytoplankton in this area together with Phaeocystis sp. Cryptophytes were encountered throughout the WS in a wide range of concentrations, reaching a peak of 162,698 cells $1^{-1}$ in the north (station 113). Dinoflagellates were present in all sampling stations $\left(\bar{x}=34,326\right.$ cells $\left.1^{-1}\right)$ with a maximum concentration of 111,111 cells $1^{-1}$ in the southern neritic area (station 140) (Table 5).

Fragilariopsis abundance was high across the WS $\left(\bar{x}=110,563\right.$ cells $\left.1^{-1}\right)$, representing $5.61 \%$ of total phytoplankton and $7.08 \%$ of total diatom density, although in six out of nineteen stations, we did not find Fragilariopsis. North and west of station $133\left(\sim 70^{\circ} \mathrm{S}-31^{\circ} \mathrm{W}\right)$, Fragilariopsis occurred in low concentrations, except at stations 122 and 124 where we found this genus at an average density of 45,595 cells $1^{-1}$. Specifically at station $124, F$. curta was the 
Table 5 Phytoplankton, diatom and Fragilariopsis abundance (cells $1^{-1}$ ) collected during ARGAU I including Fragilariopsis concentration as percentage of total phytoplankton and diatoms

\begin{tabular}{|c|c|c|c|c|c|c|c|}
\hline \multirow[t]{2}{*}{ Area } & \multirow[t]{2}{*}{ Station } & \multirow{2}{*}{$\begin{array}{l}\text { Total } \\
\text { Phytoplankton } \\
\left(\text { cells } 1^{-1} \text { ) }\right.\end{array}$} & \multirow{2}{*}{$\begin{array}{l}\text { Phytoflagellates } \\
\leq 5 \mu \mathrm{m} \\
\left(\text { cells } 1^{-1} \text { ) }\right.\end{array}$} & \multirow{2}{*}{$\begin{array}{l}\text { Diatoms } \\
\left(\text { cells } 1^{-1} \text { ) }\right.\end{array}$} & \multicolumn{3}{|c|}{ Fragilariopsis spp. } \\
\hline & & & & & $\left(\right.$ cells $\left.1^{-1}\right)$ & $\begin{array}{l}\% \text { respect to total } \\
\text { Phytoplankton }\end{array}$ & $\begin{array}{l}\% \text { respect to } \\
\text { Diatoms }\end{array}$ \\
\hline \multirow[t]{11}{*}{ AS } & 86 & 841,667 & 406,250 & 4,167 & $\mathrm{a}$ & 0.00 & 0.00 \\
\hline & 88 & $1,066,667$ & $1,027,778$ & a & a & 0.00 & 0.00 \\
\hline & 89 & 936,667 & 853,333 & 6,667 & $\mathrm{a}$ & 0.00 & 0.00 \\
\hline & 90 & $4,010,417$ & $3,682,292$ & 109,375 & 109,375 & 2.73 & 100.00 \\
\hline & 92 & $8,266,667$ & $8,158,333$ & a & a & 0.00 & 0.00 \\
\hline & 93 & $1,762,500$ & $1,745,833$ & a & a & 0.00 & 0.00 \\
\hline & 94 & 934,722 & 884,722 & 5,556 & a & 0.00 & 0.00 \\
\hline & 96 & 601,667 & 485,000 & 10,000 & a & 0.00 & 0.00 \\
\hline & 99 & 240,278 & 156,944 & 13,889 & a & 0.00 & 0.00 \\
\hline & 100 & 327,083 & 310,417 & $\mathrm{a}$ & a & 0.00 & 0.00 \\
\hline & & $\bar{x}=1,898,833$ & $\bar{x}=1,771,090$ & $\bar{x}=14,965$ & & & \\
\hline \multirow[t]{8}{*}{ DP } & 102 & 465,278 & 413,889 & 15,278 & 5,556 & 1.19 & 36.37 \\
\hline & 103 & 89,583 & 71,528 & 9,028 & 2,778 & 3.10 & 30.77 \\
\hline & 104 & 505,556 & 422,222 & 11,111 & 1,389 & 0.27 & 12.50 \\
\hline & 105 & 251,042 & 184,375 & 42,708 & 37,500 & 14.94 & 87.80 \\
\hline & 106 & $1,883,333$ & 991,667 & 425,000 & 100,000 & 5.31 & 23.53 \\
\hline & 108 & $1,035,714$ & 57,540 & 950,397 & 65,476 & 6.32 & 6.89 \\
\hline & 110 & $1,197,222$ & $1,000,000$ & 52,778 & 22,222 & 1.86 & 42.10 \\
\hline & & $\bar{x}=775,390$ & $\bar{x}=448,746$ & $\bar{x}=215,186$ & $\bar{x}=33,560$ & $\bar{x}=4.33$ & $\bar{x}=15.6$ \\
\hline \multirow[t]{20}{*}{ WS } & 112 & $1,133,333$ & 986,667 & 30,000 & $\mathrm{a}$ & 0.00 & 0.00 \\
\hline & 113 & 505,952 & 115,079 & 170,635 & a & 0.00 & 0.00 \\
\hline & 117 & 115,000 & 19,167 & 35,000 & 2,500 & 2.17 & 7.14 \\
\hline & 119 & 294,048 & 227,381 & 53,571 & 16,667 & 5.67 & 31.11 \\
\hline & 120 & 362,403 & 81,395 & 251,938 & $\mathrm{a}$ & 0.00 & 0.00 \\
\hline & 122 & 587,838 & 286,036 & 250,000 & 56,306 & 9.58 & 22.52 \\
\hline & 124 & 153,101 & 93,023 & 36,822 & 34,884 & 22.78 & 94.74 \\
\hline & 128 & 53,125 & 44,792 & 8,333 & $\mathrm{a}$ & 0.00 & 0.00 \\
\hline & 129 & 245,471 & 136,775 & 3,623 & $\mathrm{a}$ & 0.00 & 0.00 \\
\hline & 130 & 360,000 & 233,333 & 6,667 & a & 0.00 & 0.00 \\
\hline & 133 & $1,705,556$ & $1,300,000$ & 266,667 & 116,667 & 6.84 & 43.75 \\
\hline & 134 & 916,667 & 560,000 & 186,667 & 73,333 & 8.00 & 39.29 \\
\hline & 135 & 833,333 & 511,905 & 133,929 & 32,738 & 3.93 & 24.44 \\
\hline & 137 & 794,444 & 25,000 & 227,778 & 119,444 & 15.03 & 52.44 \\
\hline & 138 & $1,657,407$ & 652,778 & 796,296 & 351,852 & 21.23 & 44.19 \\
\hline & 139 & $7,370,370$ & $\mathrm{a}$ & $7,287,037$ & 64,815 & 0.88 & 0.89 \\
\hline & 140 & $8,166,667$ & 18,519 & $8,037,037$ & 527,778 & 6.46 & 6.57 \\
\hline & 142 & $6,092,593$ & 101,852 & $5,898,148$ & 194,444 & 3.19 & 3.30 \\
\hline & 143 & $6,111,111$ & 9,259 & $6,009,259$ & 509,259 & 8.33 & 8.47 \\
\hline & & $\bar{x}=1,971,496$ & $\bar{x}=284,366$ & $\bar{x}=1,562,600$ & $\bar{x}=110,563$ & $\bar{x}=5.61$ & $\bar{x}=7.08$ \\
\hline
\end{tabular}

AS Argentine Sea, DP Drake Passage, WS Weddell Sea

${ }^{a}$ Below detection limit

dominant diatom. From station 133 toward the south, the density of the genus becomes higher, from 32,738 (station 135 ) to 527,778 cells $1^{-1}$ (station 140). In the south-eastern WS, at stations 133, 134, 137 and 138, Fragilariopsis was the dominant diatom genus, with $F$. curta abundance varying from 60,000 to 240,741 cells $1^{-1}$. In contrast, between the stations 139 and 143 over the continental shelf, total phytoplankton was dominated by the $D$. antarcticus bloom (Table 5; Balestrini et al. 2000). The density of Fragilariopsis also remained high $\left(\bar{x}=324,074\right.$ cells $\left.1^{-1}\right)$. Our results agree with previous findings depicting Fragilariopsis species as dominant diatoms in the WS during the summer (Estrada and Delgado 1990). More specifically, Hegseth and von Quillfeldt (2002) found $F$. curta as a dominant diatom in 

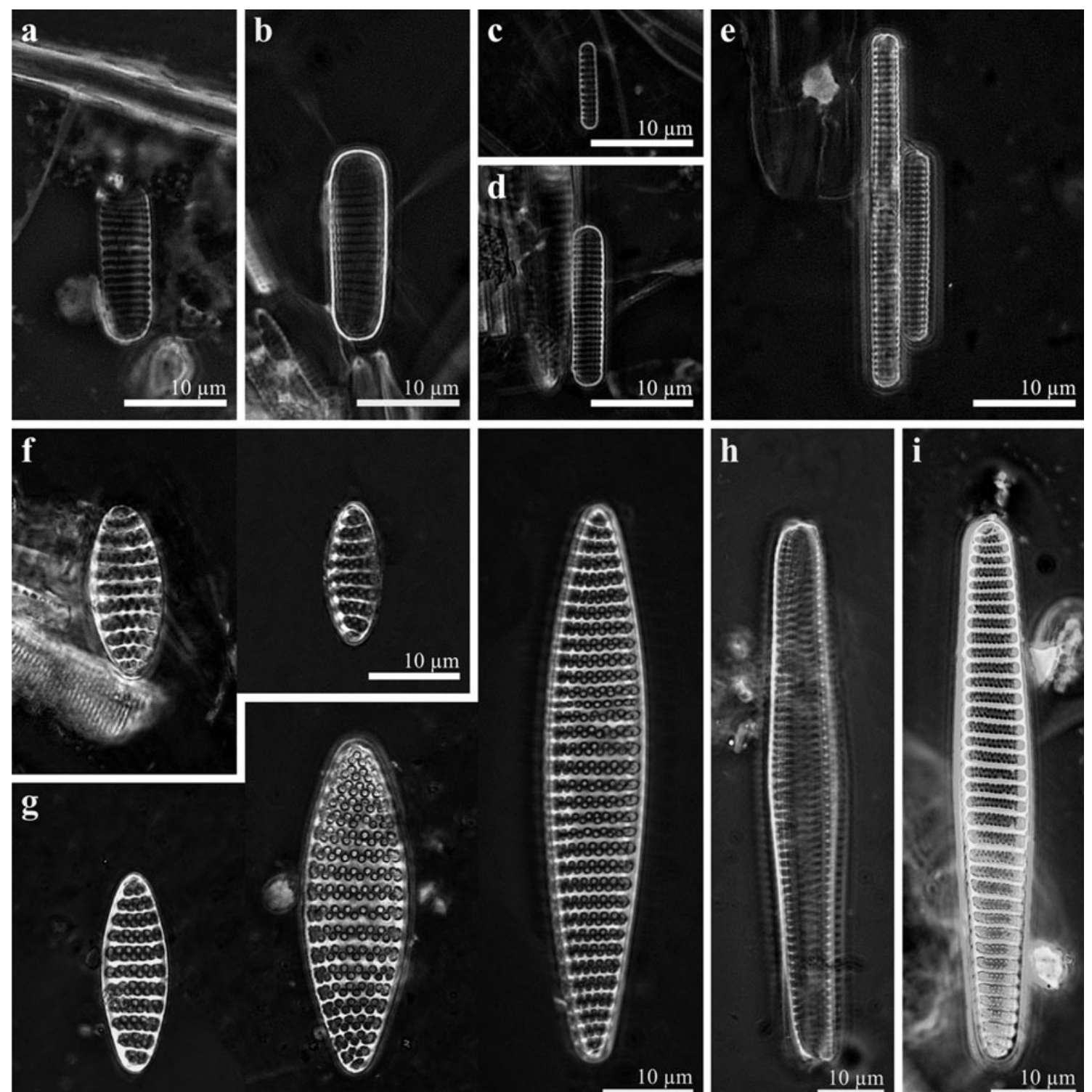

Fig. 7 a-i Frenguelli Diatom Collection. a, b (slides 61 and 62) Specimens placed as Fragilariopsis linearis var. curta in Frenguelli (1960), equivalent to F . curta. c-e (slide 63) Fragilariopsis cylindrus/ nana specimens that Frenguelli in Frenguelli and Orlando (1958) based the transfer of Fragilaria cylindrus to Fragilariopsis. $\mathbf{f}$ (slide 61) Specimens corresponding to Fragilariopsis antarctica var.

the south-eastern part of the WS, close to the ice shelf; F. cylindrus is cited as an abundant species in coastal and ice-edge zones (Kozlova 1966); and during late summer/ early autumn, $F$. cylindrus and $F$. curta can dominate most of the phytoplankton community in the north-western WS, near the ice edge (Kang and Fryxell 1993).

\section{Conclusions}

The present study demonstrated that Fragilariopsis contains a homogeneous group of species. It is a small
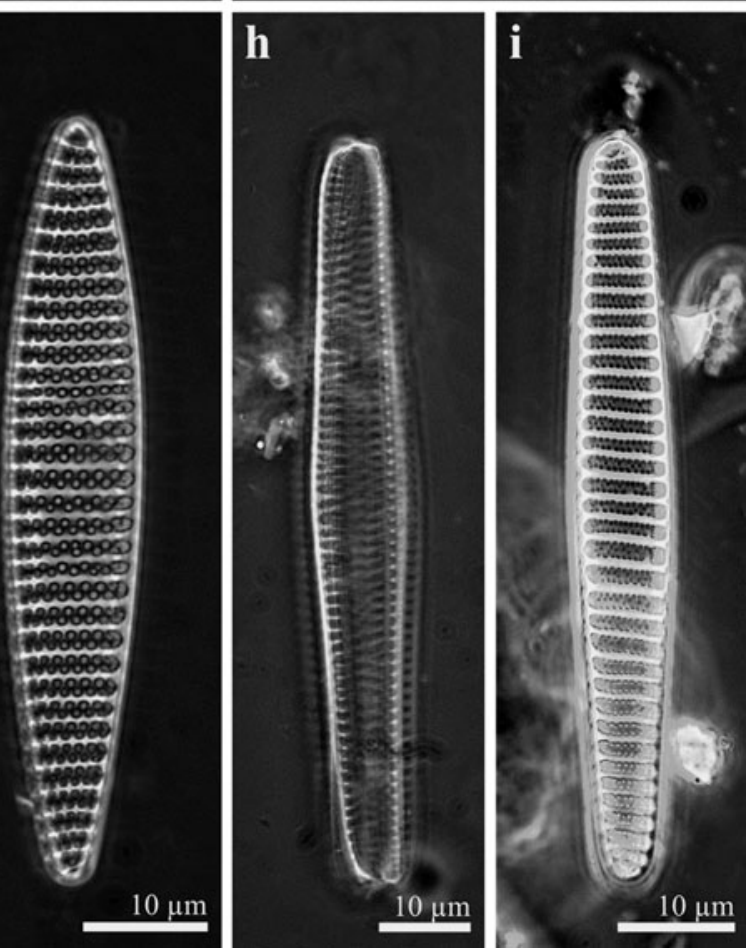

elliptica Frenguelli, rejected by Hasle (1965). g (slide 61) Fragilariopsis kerguelensis specimens corresponding to the type species. h (slide 911) Specimen identified as Fragilariopsis sublinearis by Frenguelli (1943), corresponding to $F$. obliquecostata. i (slide 46) Specimen identified by Frenguelli and Orlando (1958) as Fragilariopsis obliquecostata f. maxima, equivalent to $F$. obliquecostata

genus of $\sim 20$ species with great morphological similarity among some of these species in their diagnostic characters.

In this paper, twelve species of Fragilariopsis genus are documented in the study area, of which $F$. pseudonana is a new record for the Argentine Sea. This is the first time $F$. peragallii was analyzed using electron microscopy. The results provide new information (from SEM) on the girdle structure for most of the species, except for $F$. curta, $F$. cylindrus and $F$. nana, for which information already existed. 
Our observation shows that the valve mantle can be unperforated or perforated by one row of poroids, which can occur in groups of two to five, except for $F$. sublinearis and $F$. oceanica (the latter not included in the present work), whose mantles are striated. In addition, the pattern of poroids on the valve mantle of $F$. cylindrus and $F$. sublinearis is different on the proximal and distal sides. The present analysis supports the assertion that the arrangement of the poroids on the valve mantle could be an additional taxonomic character to distinguish some Fragilariopsis species, notably $F$. cylindrus and $F$. sublinearis (including F. oceanica).

We found the cingulum to be composed of two to three copulae. The valvocopula presents an advalvar row of poroids, and it is rarely unperforated, whereas the copulae are always unperforated.

Our study confirms the view presented in the literature that morphometric and morphological data from the valve view are of great taxonomic significance, mainly when used in combination with the girdle view information.

According to the polarity of the valves, we recognize two main groups of species. In the first group, with isopolar valves, we place most of the examined species, $F$. cylindrus, F. nana, F. peragallii, F. pseudonana, F. rhombica, $F$. separanda, F. sublinearis and $F$. vanheurckii. In the second group, with heteropolar valves, we place $F$. curta and $F$. ritscheri. Two Other species, F. kerguelensis and F. obliquecostata, vary between isopolar and heteropolar. The former occasionally varies according to size, with heteropolarity more evident in the larger specimens; the latter is only slightly heteropolar, independent of size.

The comparison of our material with the original samples from the "Colección de Diatomeas Argentinas Dr. J. Frenguelli" (Fig. 7) gave us the opportunity to corroborate the species identified, synonyms and transfers made by Frenguelli for material collected in the same areas, some of them later rejected.

Our data show phytoplankton are in greater total numerical abundance in the AS and in neritic waters of the WS, with unidentified small phytoflagellates dominating in the first region and diatoms in the second one. High phytoplankton abundance can also be found in particular areas in this north-south transect, as seen in the south-east of the DP. Furthermore, this study stresses the importance of the Fragilariopsis genus in Antarctic phytoplankton. Although present in the Argentine Sea, the genus becomes diverse and abundant only in south of the Polar Front. Of the twelve species of Fragilariopsis documented, four occurred in the AS, nine in the DP and twelve in the WS. $F$. curta, F. kerguelensis, $F$. pseudonana and $F$. rhombica were present in all of the studied areas. Fragilariopsis was the most abundant diatom genus in one station of the AS, two stations of the DP and five stations of the WS, with
$F$. pseudonana, $F$. kerguelensis and $F$. curta being the dominant forms at each region, respectively. Fragilariopsis species can be abundant in mixed blooms, as seen with Dactyliosolen antarcticus in the south-east Weddell Sea (e.g., Table 5) or Pseudo-nitzschia heimii at the Polar Front.

With respect to the findings of Fragilariopsis species in the sediment, except for the consideration made by Hasle for $F$. vanheurckii, we infer that these come from the water column as well as from the ice.

Acknowledgments This study was supported in part by grants from Argentina (CONICET: PIP 5603, ANPCyT-Pict 2004, GEF-PNUD ARG 02/18) and from the USA, National Science Foundation, awards ANT-0529815, ANT-0650034 to K. Smith and ANT-0636730 to M. Vernet. We thank P. Sarmiento and Dr. S. Licea for their excellent technical assistance with SEM and TEM work in EM Services of the Museo de La Plata, Argentina and in Universidad Nacional Autónoma de México, Mexico City, respectively. We extend our deep appreciation to the Instituto Antártico Argentino (IAA), the officers and crew on the ARA Almirante Irizar and ARA Puerto Deseado, ARSV LM Gould and ARIB NB Palmer during sample collection. The authors acknowledge M. Charo and H. Isbert from Servicio de Hidrografía Naval (Argentina) for assistance during manuscript preparation. Special thanks are given to M. Andrews and E. Torre for assistance during early stages of the manuscript preparation. We thank A. Narwani for critically reading this paper. Finally, we want to express our gratitude to reviewers who with their valuable suggestions made us improve our paper.

Open Access This article is distributed under the terms of the Creative Commons Attribution Noncommercial License which permits any noncommercial use, distribution, and reproduction in any medium, provided the original author(s) and source are credited.

\section{References}

Abelmann A, Gersonde R, Cortese G, Kuhn G, Smetacek V (2006) Extensive phytoplankton blooms in the Atlantic sector of the glacial Southern Ocean. Paleoceanography 21 PA1013. doi: 10.1029/2005PA001199

Akselman R (1996) Estudios ecológicos en el Golfo San Jorge y adyacencias (Atlántico Sudoccidental). Distribución, abundancia y variación estacional del fitoplancton en relación a factores físico-químicos y la dinámica hidrológica. Ph.D. thesis, Facultad de Ciencias Exactas y Naturales, Universidad de Buenos Aires

Almandoz GO, Ferrario ME, Ferreyra GA, Schloss IR, Esteves JL, Paparazzo FE (2007) The genus Pseudo-nitzschia (Bacillariophyceae) in continental shelf waters of Argentina (Southwestern Atlantic Ocean, 38-55 ${ }^{\circ}$ ). Harmful Algae 6:93-103

Almandoz GO, Ferreyra GA, Schloss IR, Dogliotti AI, Rupolo V, Paparazzo FE, Esteves JL, Ferrario ME (2008) Distribution and ecology of Pseudo-nitzschia species (Bacillariophyceae) in surface waters of the Weddell Sea (Antarctica). Polar Biol 31:429-442

Antoniades D, Hamilton PB, Douglas MSV, Smol JP (2008) Diatoms of North America: The freshwater floras of Prince Patrick, Ellef Ringnes and northern Ellesmere Islands from the Canadian Arctic Archipelago. Iconographia Diatomologica, vol 17. ARG, Gantner Verlag, Ruggell 
Arrigo KR, Robinson DH, Worthen DL, Dunbar RB, DiTullio GR, vanWoert M, Lizotte MP (1999) Phytoplankton community structure and the drawdown of nutrients and $\mathrm{CO}_{2}$ in the Southern Ocean. Science 283:365-367

Balestrini CF, Poisson AR, Ferreyra GA, Ferrario ME, Schauer B, Schloss IR, Molina DA, Sala H, Bianchi AA, Ruiz-Pino D, Piola AR, Saraceno M (2000) Project "ARGAU". Preliminary datareport I/B A.R.A. Almte. Irizar, Cruise ARGAU ZERO. Inst Ant Arg, Contr 529:1-30

Barlow RG, Mantoura RFC, Cummings DG (1998) Phytoplankton pigment distributions and associated fluxes in the Bellingshausen Sea during the austral spring 1992. J Mar Syst 17:97-113

Brandini FP, Boltovskoy D, Piola A, Kocmur S, Röttgers R, Abreu PC, Mendes Lopes R (2000) Multiannual trends in fronts and distribution of nutrients and chlorophyll in the southwestern Atlantic $\left(30-62^{\circ} \mathrm{S}\right)$. Deep-Sea Res I 47:1015-1033

Carreto JI, Negri R, Benavides H (1981) Fitoplancton, pigmentos y nutrientes. Resultados campañas III y VI del B/I "Shinkai Maru", 1978. Contrib Inst Nac Inv Des Pesq (Mar del Plata) 383:181-201

Cortese G, Gersonde R (2007) Morphometric variability in the diatom Fragilariopsis kerguelensis: Implications for Southern Ocean paleoceanography. Earth and Planet Sci Lett 257:526-544

Cremer H, Roberts D, McMinn A, Gore D, Melles M (2003) The Holocene diatom flora of marine bays in the Windmill Islands, East Antarctica. Bot Mar 46:82-106

Estrada M, Delgado M (1990) Summer phytoplankton distributions in the Weddell Sea. Polar Biol 10:441-449

Fernandes LF, Sar EA (2009) Fine morphology of Gomphonema margaritae Frenguelli \& Orlando and its validation and transfer to Tripterion Holmes, Nagasawa \& Takano. Diatom Res 24:63-78

Ferrario ME, Galván N (1989) Catálogo de las diatomeas marinas citadas entre los $36^{\circ}$ y los $60^{\circ} \mathrm{S}$ con especial referencia en el Mar Argentino. Inst Ant Arg Publ 20:1-327

Ferrario ME, Licea S (2006) Species of the genus Pseudo-nitzschia (Bacillariophyta) in Antarctic waters: morphology and distribution. Nov Hed Beih 130:1-16

Ferrario ME, Sar EA, Sala SE (1995) Metodología básica para el estudio del fitoplancton con especial referencia a las diatomeas. In: Alveal K, Ferrario ME, Oliveira EC, Sar EA (eds) Manual de métodos ficológicos. Univ Concepción. A Pinto Edit, Chile, pp 1-23

Ferrario ME, Licea S, Almandoz GO, Garibotti IA (2008) Species of Coscinodiscus (Bacillariophyta) from the Gulf of Mexico, Argentina and Antarctic waters: morphology and distribution. Nov Hed Beih 133:187-216

Fischer G, Gersonde R, Wefer G (2002) Organic carbon, biogenic silica and diatom fluxes in the marginal winter sea-ice zone and in the Polar Front Region: interannual variations and differences in composition. Deep-Sea Res II 49:1721-1745

Frenguelli J (1943) XVIII Contribución al conocimiento de las diatomeas argentinas. Diatomeas de las Orcadas del Sur. Rev Mus La Plata 5:221-265

Frenguelli J (1960) Diatomeas y silicoflagelados recogidos en Tierra Adélie durante las Expediciones Polares Francesas de PaulEmile Victor (1950-1952). Rev Algol 1:3-48

Frenguelli J, Orlando HA (1958) Diatomeas y silicoflagelados del Sector Antártico Sudamericano. Publ Inst Ant Arg 5:1-191

Frenguelli J, Orlando HA (1959) Operación Merluza. Diatomeas y silicoflagelados del plancton del "VI Crucero". Rep Argentina. Serv Hidr Naval, Publ Téc Ocean, H 619:1-62

Fryxell GA (1989) Marine phytoplankton at the Weddell Sea ice edge: seasonal changes at the specific level. Polar Biol 10:1-18

Fryxell GA, Kendrick GA (1988) Austral spring microalgae across the Weddell Sea ice edge: spatial relationships found along a northward transect during AMERIEZ 83. Deep-Sea Res 35:1-20
Garibotti IA, Vernet M, Ferrario ME, Smith RC, Ross RM, Quetin LB (2003) Phytoplankton spatial distribution in the western Antarctic Peninsula (Southern Ocean). Mar Ecol Progr Ser 261:21-39

Garrison DL, Buck KR (1989) The biota of Antarctic pack ice in the Weddell Sea and Antarctic Peninsula regions. Polar Biol 10:211-219

Garrison DL, Buck KR, Fryxell GA (1987) Algal assemblages in Antarctic pack ice and in ice-edge plankton. J Phycol 23:564572

Hasle GR (1964) Nitzschia and Fragilariopsis species studied in the light and electron microscopes. Part I. Some marine species of the groups Nitzschiella and Lanceolatae. Skr Norske VidenskAkad I Mat-Nat K1 NS 16:1-48

Hasle GR (1965) Nitzschia and Fragilariopsis species studied in the light and electron microscopes. Part III. The genus Fragilariopsis. Skr Norske Vidensk-Akad I Mat-Nat K1 NS 21:1-49

Hasle GR (1972) Fragilariopsis as a section of the genus Nitzschia Hassall. Nov Hed Beih 39:111-119

Hasle GR (1974) Validation of the names of some marine planktonic species of Nitzschia (Bacillariophyceae). Taxon 23:425-428

Hasle GR (1976) The biogeography of some marine planktonic diatoms. Deep-Sea Res 23:319-338

Hasle GR (1993) Nomenclatural notes on marine planktonic diatoms. The family Bacillariaceae. Nov Hed Beih 106:315-321

Hasle GR, Fryxell GA (1970) Diatoms: cleaning and mounting for light and electron microscopy. Trans Am Microsc Soc 89:468-474

Hasle GR, Medlin LK (1990) Family Bacillariaceae: the genus Nitzschia section Fragilariopsis. In: Medlin LK, Priddle J (eds) Polar Marine diatoms. British Antarctic survey. Nat Env Res Counc, Cambridge, pp 181-196

Hasle GR, Syvertsen EE (1997) Marine diatoms. In: Tomas CR (ed) Identifying marine phytoplankton. Academic Press, San Diego, pp 5-385

Hegseth EN, von Quillfeldt CH (2002) Low phytoplankton biomass and ice algal blooms in the Weddell Sea during the ice-filled summer of 1997. Antarctic Sci 14:231-243

Heiden H, Kolbe RW (1928) Die marinen Diatomeen der deutschen Südpolar-expedition 1901-1903. Deutsch Südpol Exped. 1901-1903, 8:447-715

Hooker JDS (1844) The botany of the Antarctic voyage of H M discovery ships Erebus and Terror in the years 1839-1843, under the command of Captain Sir James Clark Ross. Reeve Brothers, London

Hustedt F (1913) In Schmidt A (1874-1959) Atlas der Diatomaceenkunde. Reisland, Leipzig

Hustedt F (1952) Diatomeen aus der Lebensgemeinschaft des Buckelwals (Megaptera nodosa Bonn.). Arch Hydrobiol 46:286298

Hustedt F (1958) Diatomeen aus der Antarktis und dem Südatlantik. Dtsch Antarkt Exped 1938/39 2:103-191

Kang S-H, Fryxell GA (1992) Fragilariopsis cylindrus (Grunow) Krieger: The most abundant diatom in water column assemblages of Antarctic marginal ice edge zones. Polar Biol 12:609627

Kang S-H, Fryxell GA (1993) Phytoplankton in the Weddell Sea, Antarctica: composition, abundance and distribution in watercolumn assemblages of the marginal ice-edge zone during austral autumn. Mar Biol 116:335-348

Kang S-H, Lee S (1995) Antarctic phytoplankton assemblage in the western Bransfield Strait region, February 1993: composition, biomass, and mesoscale distributions. Mar Ecol Progr Ser 129:253-267

Kang S-H, Kang JS, Lee S, Chung KH, Kim D, Park MG (2001) Antarctic phytoplankton assemblages in the marginal ice zone of the northwestern Weddell Sea. J Plankton Res 23:333-352 
Kopczyńska EE, Goeyens L, Semeneh M, Dehairs F (1995) Phytoplankton composition and cell carbon distribution in Prydz Bay, Antarctica-Relation to organic particulate matter and its delta-C-13 values. J Plankton Res 17:685-707

Kopczyńska EE, Savoye N, Dehairs F, Cardinal D, Elskens M (2007) Spring phytoplankton assemblages in the Southern Ocean between Australia and Antarctica. Polar Biol 31:77-88

Kozlova OG (1966) Diatoms of the Indian and Pacific sectors of the Antarctic. [transl from Russ] NSF, Washington. DCS Monson, Jerusalem

Kozlowski WA (2008) Pigment derived phytoplankton composition along the Western Antarctic Peninsula. Thesis, Master of Science, San Diego State University

Krell A, Schnack-Schiel SB, Thomas DN, Kattner G, Zipan W, Dieckmann GS (2005) Phytoplankton dynamics in relation to hydrography, nutrients and zooplankton at the onset of sea ice formation in the eastern Weddell Sea (Antarctica). Polar Biol 28:700-713

Lange KB (1985) Spatial and seasonal variations of diatom assemblages off the Argentinian coast (South Western Atlantic). Oceanol Acta 8:361-370

Longhurst A (1998) Ecological geography of the sea. Academic Press, San Diego

Lundholm N, Hasle GR (2008) Are Fragilariopsis cylindrus and Fragilariopsis nana bipolar diatoms?-Morphological and molecular analyses of two sympatric species. Nov Hed Beih 133:231-250

Lundholm N, Daugbjerg N, Moestrup Ø (2002) Phylogeny of the Bacillariaceae with emphasis on the genus Pseudo-nitzschia (Bacillariophyceae) based on partial LSU rDNA. Eur J Phycol 37:115-134

Manguin E (1960) Les diatomées de la Terre Adélie. Campagne du Commandant Charcot 1949-1950. Ann Sci Nat (Bot) 12:223363

Medlin LK, Sims PA (1993) The transfer of Pseudoeunotia doliolus to Fragilariopsis. Nov Hed Beih 106:323-334

O'Meara E (1877) On the diatomaceous gatherings made at Kerguelen's Land. J Linn Soc Bot 15:55-59

Olguín HF, Boltovskoy D, Lange CB, Brandini F (2006) Distribution of spring phytoplankton (mainly diatoms) in the upper $50 \mathrm{~m}$ of the Southwestern Atlantic Ocean $\left(30-61^{\circ} \mathrm{S}\right)$. J Plankton Res 28:1107-1128

Peragallo M (1921) Deuxième Expédition Antarctique Française 1908-1910 Commandée par le Dr. Jean Charcot. Botanique. Diatomées d'eau douce et diatomées d'eau salée. Masson, Paris, pp 1-98

Prézelin BB, Hofmann EE, Moline M, Klinck JM (2004) Physical forcing of phytoplankton community structure and primary production in continental shelf waters of the Western Antarctic Peninsula. J Mar Res 62:419-460

Romero O, Hensen C (2002) Oceanographic control of biogenic opal and diatoms in surface sediments of the Southwestern Atlantic. Mar Geol 186:263-280
Romero SI, Piola AR, Charo M, Eiras García CA (2006) Chlorophyll- $a$ variability off Patagonia based on SeaWIFS data. J Geophys Res 111:C05021. doi:10.1029/2005JC003244

Round FE, Crawford RM, Mann DG (1990) The diatoms, biology \& morphology of the genera. Cambridge Univ Press, Cambridge

Schloss IR, Estrada M (1994) Phytoplankton composition in the Weddell-Scotia Confluence area during austral spring in relation to hydrography. Polar Biol 14:77-90

Schloss IR, Ferreyra GA, Ferrario ME, Almandoz GO, Codina R, Bianchi AA, Balestrini CF, Ochoa HA, Ruiz Pino D, Poisson A (2007) Role of plankton communities in the sea-air variation of $p \mathrm{CO}_{2}$ in the SW Atlantic Ocean. Mar Ecol Progr Ser 332:93-106

Scott FJ, Marchant HJ (2005) Antarctic marine protists. Australian Biological Resources Study, Canberra

Simonsen R (1974) The diatom plankton of the Indian Ocean Expedition of RV "Meteor" 1964-1965. "Meteor" Forschungsergebnisse Reihe D 19:1-107

Smith KL Jr, Robison BH, Helly JJ, Kaufmann RS, Ruhl HA, Shaw TJ, Twining BS, Vernet M (2007) Free-drifting icebergs: hot spots of chemical and biological enrichment in the Weddell Sea. Science 317:478-482

Socal G, Nöthig EM, Bianchi F, Boldrin A, Mathot S, Rabitti S (1997) Phytoplankton and particulate matter at the Weddell/ Scotia Confluence $\left(47^{\circ} \mathrm{W}\right)$ in summer 1989 , as a final step of a temporal succession (EPOS project). Polar Biol 18:1-9

Utermöhl H (1958) Zur Vervollkommnung der quantitativen Phytoplankton-Methodik. Mitt Int Ver theor angew Limnol 9:1-38

van Heurck H (1909) Diatomées. In: Expédition antarctique belge. Résultates du voyage du S.Y. Belgica 1897-1899. Buschmann, Antwerp

van Leeuwe MA, De Baar HJW, Veldhuis MJW (1998) Pigment distribution in the Pacific region of the Southern Ocean (autumn 1995). Polar Biol 19:348-353

Villafañe VE, Helbling EW, Holm-Hansen O (1995) Spatial and temporal variability of phytoplankton biomass and taxonomic composition around Elephant Island, Antarctica, during the summers of 1990-1993. Marine Biol 123:677-686

Vouilloud AA (2003) Catálogo de diatomeas continentales y marinas de Argentina. Asoc Arg Ficol, La Plata. Vers 1.0. ISBN 98721041-0-7. [Digital format]

Walsh JJ, Dieterle DA, Lenes J (2001) A numerical analysis of carbon dynamics of the Southern Ocean phytoplankton community: the roles of light and grazing in effecting both sequestration of atmospheric $\mathrm{CO}_{2}$ and food availability to larval krill. Deep-Sea Res I 48:1-48

Zielinski U, Gersonde R (1997) Diatom distribution in Southern Ocean surface sediments (Atlantic sector): Implications for paleoenvironmental reconstructions. Palaeogr Palaeoclim Palaeocol 129:213-250 